\title{
Decent work, standards and indicators
}

\author{
Working Paper No. 58
}

\author{
Monique Zarka-Martres* \\ and Monique Guichard-Kelly**
}

\author{
Statistical Development and Analysis Group \\ Policy Integration Department \\ International Labour Office \\ Geneva
}

August 2005

Working papers are preliminary documents circulated to stimulate discussion and obtain comments

* Department of International Labour Standards

**Consultant, Department of International Labour Standards 
Copyright $@$ International Labour Organization 2005

Publications of the International Labour Office enjoy copyright under Protocol 2 of the Universal Copyright Convention. Nevertheless, short excerpts from them may be reproduced without authorization, on condition that the source is indicated. For rights of reproduction or translation, application should be made to the Publications Bureau (Rights and Permissions), International Labour Office, CH-1211 Geneva 22, Switzerland. The International Labour Office welcomes such applications.

Libraries, institutions and other users registered in the United Kingdom with the Copyright Licensing Agency, 90 Tottenham Court Road, London W1T 4LP [Fax: (+44) (0)20 7631 5500; email: cla@cla.co.uk], in the United States with the Copyright Clearance Center, 222 Rosewood Drive, Danvers, MA 01923 [Fax: (+1) (978) 750 4470; email: info@copyright.com] or in other countries with associated Reproduction Rights Organizations, may make photocopies in accordance with the licences issued to them for this purpose.

\section{ISBN 92-2-117923-0 (printed version)}

92-2-117924-9 (web version)

First published 2005

Cover:

\footnotetext{
The designations employed in ILO publications, which are in conformity with United Nations practice, and the presentation of material therein do not imply the expression of any opinion whatsoever on the part of the International Labour Office concerning the legal status of any country, area or territory or of its authorities, or concerning the delimitation of its frontiers.

The responsibility for opinions expressed in signed articles, studies and other contributions rests solely with their authors, and publication does not constitute an endorsement by the International Labour Office of the opinions expressed in them.

Reference to names of firms and commercial products and processes does not imply their endorsement by the International Labour Office, and any failure to mention a particular firm, commercial product or process is not a sign of disapproval.

ILO publications can be obtained through major booksellers or ILO local offices in many countries, or direct from ILO Publications, International Labour Office, $\mathrm{CH}-1211$ Geneva 22, Switzerland. Catalogues or lists of new publications are available free of charge from the above address, or by email: pubvente@ilo.org

Visit our website: www.ilo.org/publns
} 


\section{Decent work, standards and indicators}

\section{Contents}

Preface iii

List of abbreviations $\mathrm{V}$

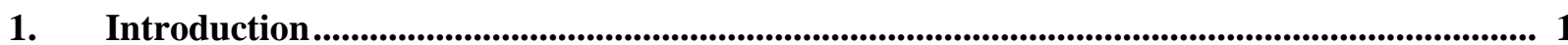

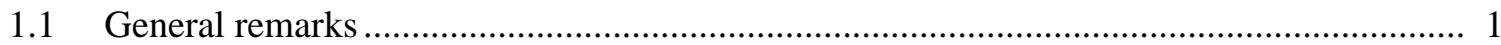

1.2 From the integrated approach to standards-related activities to a methodology for "normative" indicators

2. Taking a snapshot of the national legislative system through the lens of

ILO standards methodology. 3

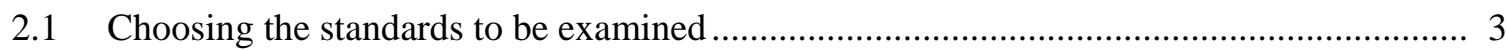

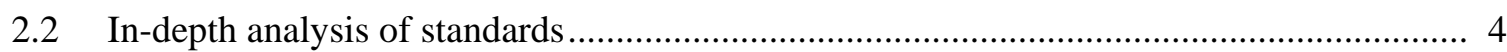

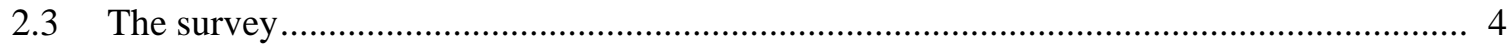

2.4 Choosing criteria/normative indicators for the country profiles ........................................ 5

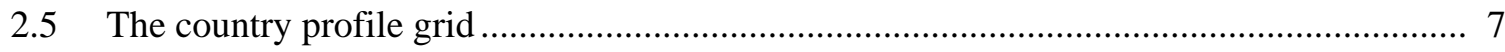

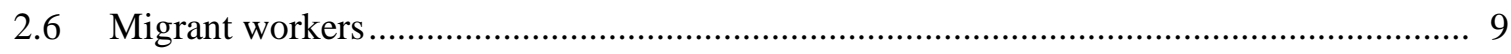

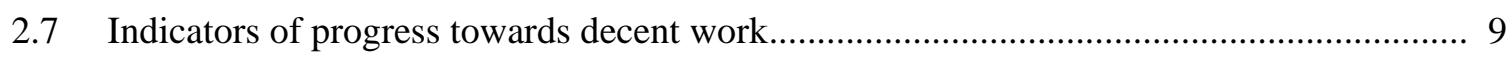

3. Hurdles in developing the normative indicators and country profiles...................................10

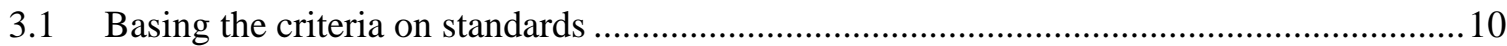

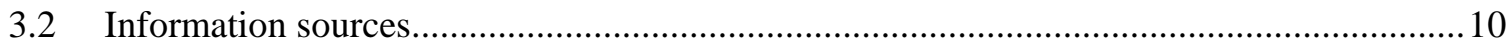

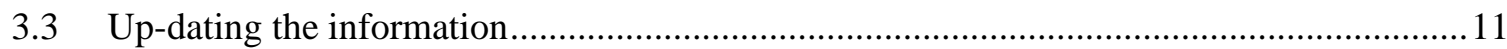

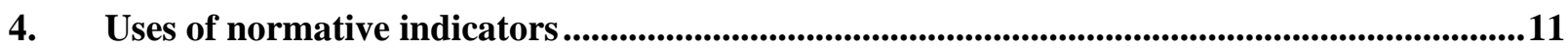

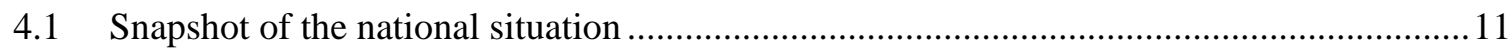

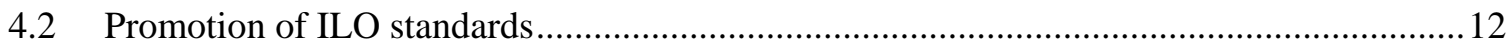

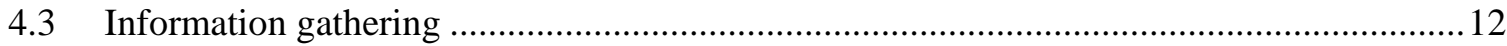

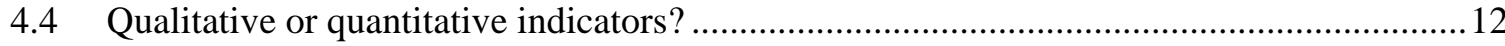

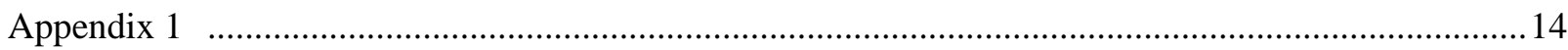

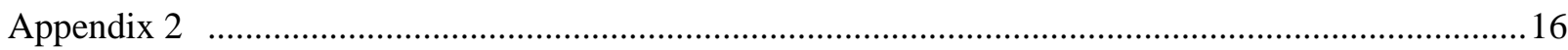

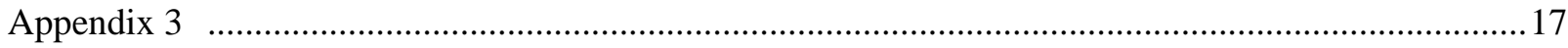

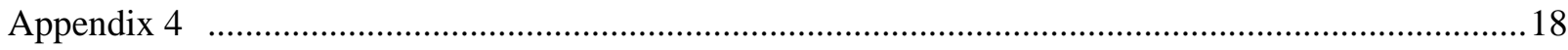

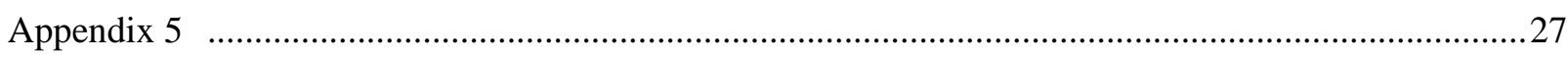

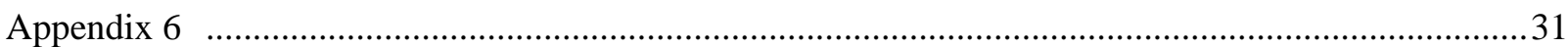




\title{
Preface
}

In September of 2004, the Policy Integration Department organized a technical staff seminar bringing together leading experts within and outside the ILO on so-called "qualitative" indicators of international labour standards. Recent years have seen a rapidly growing interest in the construction and use of such qualitative indicators among both researchers and policy-makers. This growth is arguably attributable to several factors, such as debates on the economics of labour standards, growing interest in socially responsible investing, and the recognition that statistics that are commonly used as quantitative indicators of labour standards are of limited value in capturing many aspects of labour standards and their application. Qualitative indicators of labour standards and worker rights, while they could be numerical, address things that are intrinsically more qualitative in nature and are based, for example, on methods such as grading by experts and the coding of legislation and other textual sources. The rapidly growing interest in such qualitative indicators raises a number of questions about comparative methods for the construction of these indicators as well as the appropriateness of particular methods for particular uses, and these questions were the focus of the seminar.

"Decent Work, Standards and Indicators" was one of the papers presented at the seminar. In this paper, the authors present a highly detailed and comprehensive method for constructing country profiles based on normative indicators as a tool for progress towards decent work. Country profiles on occupational safety and health (OSH) are available online for a large number of countries. Among the aspects of OSH considered are national OSH policy; the scope of application; methods of implementation; preventive and protective measures; organizational frameworks, mechanisms and measures; and powers, obligations, duties and rights. The subject of migrant workers is also covered. Information used to construct the country profiles derives from both surveys sent to ILO member states as well as from secondary sources.

As a Working Paper, this document is intended to stimulate discussion and encourage others to pursue further work to expand knowledge in relation to the ILO's Decent Work Agenda.

\author{
Peter Peek \\ Manager \\ Statistical Development and Analysis Group \\ Policy Integration Department \\ International Labour Office
}

August 2005 


\section{List of abbreviations}

C Convention

CEACR Committee of Experts on the Application of Conventions and Recommendations

ILC International Labour Conference

ILOLEX Acronym of ILO database on international labour standards

LABORSTA Acronym of ILO database on labour statistics

NATLEX Acronym of ILO database on national legislation

NORMES Acronym of the International Labour Standards Department

OSH Occupational safety and health

$\mathrm{R} \quad$ Recommendation

WPRS Working party regarding the revision of standards 



\section{Introduction}

\section{$1.1 \quad$ General remarks}

The mandate of the International Labour Organisation is to promote social justice. The preamble of its Constitution, established in 1919, begins with these words that are still fully pertinent today: "Whereas universal and lasting peace can be established only if it is based upon social justice; And whereas conditions of labour exist involving such injustice, hardship and privation to large numbers of people as to produce unrest so great that the peace and harmony of the world are imperilled; and an improvement of those conditions is urgently required". In 1999, the Director-General of the ILO, Juan Somavia, defined the mission of the ILO in today's world in the following terms: "The ILO's mission is to improve the situation of human beings in the world of work. Today, that mission finds resonance in the widespread preoccupation of people at times of great change: to find sustainable opportunities for decent work. The primary goal of the ILO today is to promote opportunities for women and men to obtain decent and productive work, in conditions of freedom, equity, security and human dignity."1

The international labour standards were the first tool developed by the ILO to implement its mandate. Today, this tool remains the most important means the Organisation has at its disposal to achieve its objectives. As stated by the Director-General in 2001, "firstly, normative action helps to clarify the meaning of decent work: standards provide an authoritative answer to the question of what decent work implies in concrete terms as regards the preconditions (fundamental principles and rights), its content (work that meets certain criteria of quality and security) and the process where by it can be achieved (social dialogue). Secondly, it helps to put the Decent Work Agenda into practice: standards are a stern indicator of progress towards the achievement of ILO objectives, not through lipservice but in law and practice."

The strength of the international labour standards, in comparison to other international instruments, is that they are developed and adopted through a tripartite process involving governments, employers and workers. Their adoption at the International Labour Conference (ILC), supreme body of the Organisation, to which the 177 member States are invited to be represented by tripartite delegations, guarantees the universality of the values contained in the instruments.

To date, the International Labour Conference has adopted 185 Conventions and 195 Recommendations, which globally cover the following subjects ${ }^{3}$ : freedom of association, collective bargaining and industrial relations; forced labour; elimination of child labour and protection of children and young persons; equality of opportunity and treatment; tripartite consultation; labour administration and inspection; employment policy and promotion; vocational guidance and training; employment security; wages; working time; occupational safety and health; social security; maternity protection; social policy; migrant

${ }^{1}$ ILO, Decent work, Report of the Director-General, International Labour Conference (ILC), $87^{\text {th }}$ Session, Geneva, 1999, page 3.

2 ILO, Reducing the decent work deficit - a global challenge, Report of the Director General, International labour ILC, $89^{\text {th }}$ Session, Geneva, 2001, page 59.

${ }^{3}$ This classification was followed in the Report of the Committee of Experts on the Application of Conventions and Recommendations, Application of International Labour Standards 2004 (I), Report III (Part 1A), International Labour Conference, $92^{\text {nd }}$ Session 2004, Geneva. 
workers; seafarers; fishermen; dockworkers; indigenous and tribal peoples; and specific categories of workers.

Given the differing levels of development and priorities, it cannot be expected that all member States be able to immediately, and in all areas, implement the international labour standards. For the standards to have real impact, they must be progressively implemented through national programmes, taking into account the institutional and economic capacity of each country as well as national priorities. A tool needs to be developed to assist member States to do this by identifying areas where there are gaps or lacunae in national laws and practices with respect to the principles that underlie decent work as contained in the standards.

\section{$1.2 \quad$ From the integrated approach to standards- related activities to a methodology for "normative" indicators}

Since the 1990's, the ILO has been undergoing a process of modernising and strengthening its standards system. In particular, the Working Party on Policy regarding the Revision of Standards (WPRS) was created in 1995 to examine the contents of each of the Conventions and Recommendations and decide on whether they were up-to-date or not. It finished its work in 2002. In 1999 the report of the Director-General, which received wide support at the ILC, pointed out that "the best guarantee of credibility lies in the effectiveness of the ILO's normative activities....Improving the visibility, effectiveness and relevance of the ILO's standard setting system must become a political priority." On the basis of this report and the results of the WPRS, a new approach to standards-related activities called "the integrated approach" was adopted by the Governing Body in November $2000^{5}$.

The aim of the integrated approach is to improve the impact of standards-related activities through an integrated use of all of the means of action available to the Organisation as well as strengthening the coherence and relevance of the standards. It is also intended that this approach assist the constituents in coming up with a consensus on future standard-setting action. Finally, the integrated approach provides a framework for the systematic evaluation of standards and their impact, documenting the positive linkages between families of standards and "encouraging member States to make simultaneous progress on each of the fronts of decent work". 6

The approach is comprised of three steps. The first is an in-depth study of the standards in a determined subject as well as other instruments (e.g. codes of practices) and means of action (e.g. promotional activities, technical cooperation, development and dissemination of the information and inter-institutional cooperation) that are relevant in the area. The second step is a tripartite general discussion at the ILC, based on the study. The aim of the general discussion is to come up with a consensus on a plan of action in the area being examined. Taking into account the needs and priorities in the area, the plan of action may identify potential new subjects for standard setting, issues that should be the object of more technical instruments, as well as the necessary promotional activities, technical cooperation and inter-institutional cooperation. Thirdly, the Governing Body is invited to

\footnotetext{
${ }^{4}$ Decent work, page 7.

${ }^{5}$ GB: $279 / 4$.

${ }^{6}$ Reducing the decent work deficit - a global challenge, page 60 .
} 
make a decision on the specific consequences of this debate by implementing the plan of action adopted at the Conference.

The integrated approach was first applied at the ILC in June 2003 in the area of occupational safety and health (OSH). In 2004, the subject of migrant workers was examined and a third general discussion based on the same approach will take place in 2005 in the area of youth employment.

The idea for developing country profiles evolved after examining the wealth of information received in the responses to the OSH survey, in the context of the preparation for the General Discussion at the ILC in 2003. The purpose was to take a snapshot of the national situation by grouping together all relevant information in a given subject with respect to international labour standards in order to assist member States in implementing the decent work agenda.

The first step was to develop the particular "lens" through which a snapshot could be taken. To take the example of OSH, the standards to be examined were identified and analysed. A survey was then developed based on the main principles in the standards. Taking into account the results of the survey and on the basis of the principles in the standards, a grid containing 13 criteria was identified. These constituted the normative indicators in the area of OSH and can be considered as the ILO "lens" in this area. Secondly, the government, employer and worker responses to the survey were incorporated in the grid along with other relevant information (such as national legislation and comments of the Committee of Experts on the Application of Conventions and Recommendations (CEACR); relevant Internet links will be incorporated into the grid at a later stage). Through this lens, the ILO constituents and the Office can determine the extent to which the principles in a group of ILO standards are applied at the national level, enable member States to identify gaps in their systems and develop national programs for the gradual implementation of standards and assist the Office to better target its technical cooperation activities.

\section{Taking a snapshot of the national legislative system through the lens of ILO standards methodology}

\subsection{Choosing the standards to be examined}

With respect to OSH, 17 Conventions, 24 Recommendations and one Protocol had been adopted, addressing general OSH issues, specific risks and hazardous occupations. According to the WPRS, of these 12 Conventions and 17 Recommendations were up-todate. Therefore more weight was put on their provisions. In addition, the Labour Inspection Convention, 1947 (No. 81) and the Labour Inspection (Agriculture) Convention, 1969 (No. 129) as well as their Recommendations and Protocol were examined in this context because of their direct relevance to $\mathrm{OSH}$.

In the area of migrant workers, there were two Conventions and two Recommendations that were considered to be the comprehensive standards in the subject area. In addition to these four instruments, a number of ILO Conventions that contained provisions directly relating to migrant workers were taken into account. 
Taking the example of OSH, the first step in the process towards selecting the criteria was an in-depth analysis of the contents of the Conventions and Recommendations. Each article or paragraph in the relevant instruments was studied and regrouped into a large document that re-sorted them by theme; i.e. those relating to policy, scope of application, social dialogue, labour inspection etc. were grouped together. ${ }^{7}$

By doing this, the main principles in the subject area became apparent. These principles were then used as the basis of the survey questions. In addition, it assisted in the examination of the relationship between the different instruments ${ }^{8}$ and the establishment of a diagram for a model OSH system based on the ILO standards. ${ }^{9}$

\subsection{The survey}

In preparation for the General Discussion held at the ILC for the first two subjects, a survey was formulated and sent to member States, inviting them to consult with the most representative employers' and workers' organisations when formulating their response. In the area of OSH, the survey acted as a sort of "checklist" for member States concerning the application of a set of given ILO standards in national law and practice. In the area of migrant workers, even though they were taken into account, the survey did not fully reflect the contents of the standards. For the promotion of youth employment, no survey was undertaken given that employment promotion (in general) had recently been the object of a general survey (étude d'ensemble) undertaken by the CEACR.

On the basis of the analysis of the OSH standards, a set of common principles within the instruments were identified. In order to have a functioning OSH system, a country had to have a coherent policy, adequate preventive and protective measures, the necessary organisational frameworks and mechanisms to ensure that the different players had the required powers, rights and duties set out in national law and practice etc.

Each question in the survey was directly linked to one or more of the provisions in the OSH instruments. Annexed to the survey was a table showing the exact Article or Paragraph associated with the question being asked. ${ }^{10}$ The questions were formulated to enable yes/no answers with further details being requested where needed.

The survey was sent out to member States with a request to consult with the most representative organisations of employers and workers. In total 107 replies were received from member States, as well as 47 from the most representative employers' and workers' organisations either in addition to or independently from the responses received from governments. The tripartite responses were extremely valuable in assessing the situation in the country. In addition, they provided a valuable amount of detail, not only concerning the legislative and policy framework but also the implementation of these.

The survey served two other purposes. Firstly, it enabled an assessment of, and in fact confirmed, that ILO standards cover the most essential aspects of OSH. Secondly, it

\footnotetext{
${ }^{7}$ Appendix 1.

${ }^{8}$ Appendix 2.

${ }^{9}$ Appendix 3 .

${ }^{10}$ Appendix 4.
} 
provided a general overview on the extent to which the main principles contained in a group of international labour standards were reflected in national legislation. The survey also included questions directly concerning the impact of ILO standards on national law and practice. A large majority replied that they had used the ILO OSH Conventions as models for national law and practice. ${ }^{11}$

\subsection{Choosing criteria/normative indicators for the country profiles}

The survey responses provided most of the information required to complete the country profiles. Of the 15 questions on national law and practice in the survey, 13 criteria could be distilled. These criteria (listed below) were based on the questions that represented the most important aspects of OSH as indicated by the responses to the survey. Each criteria also has related sub-criteria and together, these constitute a set of normative indicators for $\mathrm{OSH}^{12}$ :

- The existence of a national OSH policy formulated, implemented and reviewed on a tripartite basis

- Coverage of national OSH legislation

- Existence of national preventive and protective OSH measures

- Existence of national OSH infrastructures

- Capacity and functioning of national OSH infrastructures

- Notification and recording of occupational accidents and diseases

- Occupational health

- Existence of measures for consultation, cooperation and communication at all levels

- Existence of enforcement mechanisms

- Employer responsibilities

- Workers' rights and responsibilities

- Workers' representatives rights and responsibilities

- Responsibilities of designers, producers, importers and suppliers

\footnotetext{
${ }^{11}$ The results of the analysis of the survey responses can be found in Annex II of Report [VI], ILO standards-related activities in the area of OSH, International Labour Conference 2003, ILO Geneva 2003

${ }^{12}$ Appendix 5.
} 
As with the survey, each one of these criteria can be traced back to the specific provisions in the relevant standards. In order to evaluate whether a country has implemented the criteria, it is necessary to go back and look at the full text of the relevant standards as set out in the detailed table of ILO OSH standards. For example, in order to have implemented the principles behind criteria number two (coverage of national OSH legislation), a country would have to have OSH legislation and regulations that cover all branches of economic activity in which workers are employed as well as having specific provisions covering certain occupational hazards (hazardous substances and agents, air pollution, noise and vibration, machinery, major hazard installations and manual transport) and specific sectors of economic activity (i.e. trading establishments and mining, construction, and agricultural sector). The detailed requirements are set out in the text of the relevant standards. 


\subsection{The country profile grid ${ }^{13}$}

\begin{tabular}{|l|l|l|l|l||}
\hline $\begin{array}{l}\text { Link to } \\
\text { Ratification } \\
\text { information }\end{array}$ \\
ILO occupational safety and health standards
\end{tabular}

${ }^{13}$ The grid is presented as it is intended to be viewed in its final version. A much simpler grid, without the links, was used for OSH in order to ensure that it was placed on the web within a certain delay. 
On the basis of the 13 criteria, the above grid was established. The grid is divided up into four parts. The first is the ILO criteria and sub-criteria. Each of these criteria has a box that appears when the cursor of the computer hovers over it in which appears the relevant provisions in the standards.

The second part is the self-assessment section, which is further divided into two parts: a simple yes/no response and a summary of the comments provided by the Government and organisations of employers and workers. In the responses to the OSH survey, the comments section often contained very useful information concerning the implementation of the standards in national law and practice.

The third part is the inclusion of relevant provisions in national law. In some cases, the survey responses provided this information however, for the majority of countries, it was necessary to analyse national laws and regulations in relation to the criteria with the help of NATLEX, information in the article 22 files $^{14}$, comparative analyses done by the NORMES department as well as national legislative and other websites. Where a provision in national law corresponds in whole or in part to the criteria, it was noted in this section. If it corresponds only in part, reference to the provision is often followed by the text of the provision. As the criteria may relate to a number of Articles and Paragraphs, the provisions in national law do not always correspond to the exact wording in the instruments.

The CEACR is the competent body for assessing the extent to which member States have respected their obligations under the ratified Conventions. This assessment is articulated in observations and direct requests. These comments make up the fourth part of the grid. A note is made when a country has received one of these along with the Convention and the Article to which it corresponds. The grid provides a link for the reader to go back and read the text of the observation. ${ }^{15}$ Although this source of information is limited to countries that have ratified one or more Conventions in the subject area, the information is very useful, in particular as the CEACR often highlights problems in the application of standards or cases where progress has been made. This adds to the overall snapshot of the national situation.

General information is gathered at the top of the profile letting the reader know the Conventions that have been ratified (with a link to the ratification information given on ILOLEX) the titles of up-to-date national laws and regulations (with a link to NATLEX or the relevant national legislative website) and a list of useful websites if the reader wants to get further information from the competent authorities, OSH specialist organisations or other relevant organisations.

This standards-based examination of the de jure national situation is intended to be complemented with links to other information, such as summaries of the technical cooperation activities undertaken by the ILO in this area and their results as well as summaries of best practices and a link to relevant statistical information available within the ILO.

In the case of $\mathrm{OSH}$, for example, a number of quantitative indicators have been examined (e.g. the number of prosecutions for violations of the law, the number of inspections undertaken, the number of fatal accidents at the workplace etc.). The most frequently used

\footnotetext{
${ }^{14}$ States who have ratified Conventions are obliged to send in reports on their application in national law and practice under article 22 of the ILO Constitution.

15 Full texts of the CEACR observations can be found in the ILOLEX website: http://www.ilo.org/ilolex/english/index.htm
} 
is the number of accidents and deaths at work. It should be kept in mind, however, that while countries often have differing calculation methods for the data very few developing countries have comprehensive statistical data. This information could be used to complement the qualitative information gathered concerning the legal situation.

\subsection{Migrant workers}

As stated above, the range of instruments examined in the context of the integrated approach to migrant workers, was much smaller than for OSH. As with OSH, an in-depth analysis of the four comprehensive instruments and other relevant instruments (ILO as well as UN instruments) was undertaken, as well as an examination of standards-related activities. From this analysis, a draft grid for migrant workers has been established containing normative indicators corresponding to the main principles in relevant instruments. ${ }^{16}$

In comparison to $\mathrm{OSH}$, a different approach was taken concerning the formulation of the survey. Even though standards were taken into account, they were not the only consideration. Instead of being a pure reflection of the standards, questions were formulated in order to obtain information on a broad range of subjects in law and practice, as well as economic and statistical data.

While the survey was not designed to be a "check-list" for States to see whether they implemented the standards or not, as was done for OSH, the responses received provided adequate information that can be used to fill up the grid. A project to create country profiles for the constituents that sent in replies is currently underway, although it will take a little more time to sort through and reformulate the information compared to OSH due to the different approach taken with respect to the formulation of the migrant worker survey.

\subsection{Indicators of progress towards decent work}

The important role standards have to play in achieving decent work has been highlighted above. Standards provide the framework upon which member States can evaluate their progress towards decent work for all workers. The future goal is to apply the same method used for OSH and migrant workers to all areas in order to establish specific criteria for each subject. These criteria would then make up a group of indicators (or sub-indicators), which would give a global overview of the national situation in a given country with respect to the principles contained in ILO standards.

However, given that each subject may contain a large number of criteria, it would be unrealistic to include all these in the decent work indicators. The criteria in each subject would have to be examined and distilled to establish a set of "supreme" indicators. This should also be backed up by an in-depth analysis, as was done for OSH, of all the standards to identify principles that repeat in a number of Conventions (e.g. the obligation of member States to consult with employers' and workers' organisations).

To illustrate this idea, take the example of a car that is put into the garage to undergo a technical control in order to be registered. In order to give an overall diagnostic of the car, each aspect of the car has to be tested in detail to see whether it passes the criteria set out by the Ministry of Transport. The mechanic will test the safety mechanisms (safety belt, brakes, etc.), the motor (oil, water, radiator, transmission etc.), pollution levels and so on.

\footnotetext{
${ }^{16}$ Appendix 6.
} 
When the owner comes back at the end of the day to get the car, he or she will either have a list of minor or major repairs that need to be done. Depending on the cost and inconvenience of the work to be done and his/her resources, the owner then will have to give priorities to what to do first. In case a part needs to be replaced or repaired, the garage will have in stock or will order the precise part for the car in question. On the other hand, they may be handed a clean bill of health for the car and immediately have it registered as a "decent" car.

In the same sense, at the end of the day, a member State will have a full diagnostic of the main aspects of its legislative system based on the criteria of the international labour standards. This diagnostic will give them an idea of where gaps and lacunae exist as well as areas where there are no immediate problems for each subject as well as globally. From this, they will be able to design and implement a national program for the progressive implementation of ILO standards according to their priorities and resources thus ensuring the universal application of decent work.

\section{Hurdles in developing the normative indicators and country profiles}

\subsection{Basing the criteria on standards}

National and international opinions and policies change and the ILO standards may become out-of-date or in need of revision. This puts into question the validity of some or all of the normative indicators chosen as criteria and the process of deciding what criteria to use will have to be started all over again. Nevertheless, by keeping the criteria as general and universal as possible, it is hoped that this risk has been diminished to a minimum. In addition, experience has shown in the past that international labour standards have a long shelf life and continue to be valid many years after they have been adopted.

Another aspect to take into account is how to address new instruments adopted in the subject area? This may imply that new criteria will need to be created in order to address a new principle introduced in the subject through the instrument. However, the criteria have to be seen as flexible and able to take into account changes in both national and international laws and practices. If not then the country profiles will become only a snapshot of the situation of a country at a certain time in its existence and will soon outrun its usefulness.

\subsection{Information sources}

Concerning the collection of information on law and practice related to international labour standards, it should be recalled that the ILO Constitution provides for certain tools. Pursuant to article 22 of the Constitution, member States are invited to submit reports on a regular basis to the Office on the application of the ratified conventions. In accordance with article 19, they can - at appropriate intervals as requested by the Governing Body be called upon to report on the position of their law and practice in regard to the matters dealt with in non ratified conventions or recommendations. Moreover, pursuant to article 10, the Office is empowered to collect and disseminate information relating to the international regulation of "industrial life and labour". But most of the time the information received needs to be completed.

As with any project where research needs to be done on national laws, the problem of accessibility to those laws arises. Despite the large number of countries that now have national laws on-line, there are still many, mainly developing countries that do not. Where 
no information is available from other sources such as NATLEX, this makes examining the national legislative situation very difficult.

In addition, where texts of the laws can be obtained, these are often in languages not understood by those analysing them and need to be translated before they can be examined. This again poses the problem of resources. In some cases, unofficial translations are available, however using these may put into question the reliability of the data in the profile.

Despite the best efforts in finding the latest information, in some cases, the law examined is not the most up-to-date. To diminish the risks of this, a request could be sent out to member States to check their profile before it goes on-line to ensure that the laws and regulations noted under general information are the most recent.

Finally, in certain cases the information is so complex that it takes a lot of time to sort through and come up with a comprehensive country profile. This is the case, in particular, for federal States where the subject area is regulated either at a state, regional, territorial or provincial level. The examination of such countries may take up to 10 times longer as each state has to be dealt with individually. This is also the case for countries that have a complex legal system, where there is no general law and instead, the subject area is regulated by a large number of legislative texts. However, the above problems effect the time it takes to complete a profile rather than the quality of the profile once finished.

\subsection{Up-dating the information}

In order for the country profiles to be of use beyond the few years following their examination, they will need to be up-dated regularly. This means resources and time will need to be spent in going through and up-dating each country profile.

A number of possibilities exist to make this easier. It is important that dialogue between the constituents and the ILO be maintained to ensure that all changes in national law and practice are notified to the Office. In addition, it would be necessary to establish a network comprised of standards specialists in the field and at headquarters as well as technical ILO and national experts in the different subject areas dedicated to watching out for and analysing the most up-to-date information received from constituents, up-dating the country profiles on subjects that have already been dealt with and implementing the methodology for other subjects.

\section{Uses of normative indicators}

\subsection{Snapshot of the national situation}

The main objective of the country profiles based on normative indicators is to allow member States and the Office to obtain an overview of the national situation with respect to international labour standards in a given subject area and identify areas where there are gaps in the application of the principles behind decent work.

For member States, this analysis can be used to formulate and implement a national program for the progressive implementation of the principles in certain areas (as discussed above under point 2.7). The ILO technical departments can use this information to effectively target technical cooperation activities and resources towards those countries most in need. 
These indicators also provide a tool to measure the progress each member State has made over time in the implementation of international labour standards through national laws and practices. This assists both member States in implementing and the Office in promoting the standards.

Finally, the normative indicators could be used as a vehicle to gather information on and highlight best practices in certain countries and make this available to all constituents, conclusions that were drawn from both the general discussion held on OSH (ILC 2003) ${ }^{17}$ and migrant workers (ILC 2004) ${ }^{18}$.

\subsection{Promotion of ILO standards}

The country profiles based on normative indicators serve as a promotional tool for the international labour standards concerning not only their ratification but also implementation. The OSH survey questions used to gather information for the profiles also act as a type of "checklist" for countries. After completion of the survey, countries that have not ratified are able to assess whether they already apply the main components of standards and if they do, they may decide to ratify the relevant Conventions in the subject area. It also allows for the identification of the obstacles to ratification and may encourage member States to make moves to overcome these obstacles and ratify the Conventions.

\subsection{Information gathering}

The country profiles are designed to gather all available up-to-date national legislative and other relevant information, which correspond to a set of criteria based on ILO standards, for each ILO member State. This information has been put on the internet in order to make it available to a wide range of end-users. ${ }^{19}$

The synthetic nature of the country profiles assists those dealing with the supervision of ILO Conventions, saving time researching for information and laws, providing a quick overview of the country situation, showing progress in application when looked at over time or pointing out continuing application problems.

\subsection{Qualitative or quantitative indicators?}

On the basis of the yes/no responses to the survey, it is possible to rank member States according to those that are "good" or "bad". However, doing so would only give a partial and not completely accurate appreciation of the national situation in comparison to other countries. When responding to the survey, member States interpreted the questions more or less strictly. In addition, a number of countries did not respond to all questions. It also does not take into account the fact that application may be good in one area and not in another. Such an analysis would also not take into account the differing economic situations and

${ }^{17}$ ILO, Conclusions concerning ILO standards-related activities in the area of occupational safety and health - a global strategy, Report of the Committee on Occupational Safety and Health, Provisional Record 22, Record of Proceedings Vol. II, ILC 91 ${ }^{\text {st }}$ Session, Geneva 2003, para. 17.

18 ILO, Conclusions on a fair deal for migrant workers in a global economy, Report of the Committee on Migrant Workers, Provisional Record 22, Record of Proceedings Vol. II, ILC $91^{\text {st }}$ Session, Geneva 2003, paras. 31 and 33.

${ }^{19}$ http://www.ilo.org/ilolex/english/profileframeE.htm 
levels of development within countries. The subjects being addressed are also so broad that more detailed information is needed to fully appreciate the national situation, hence the inclusion of comments from governments, employers' and workers' organizations, national laws, comments from the CEACR as well as other relevant information.

As mentioned in the introduction, standards provide an authoritative answer to defining what decent work is, i.e. they provide a level normative playing field upon which countries can assess themselves. The indicators in the country profiles are based on international labour standards, which fix the objectives that member States should strive to obtain to implement the decent work agenda. The purpose behind the country profiles is the universal implementation of the decent work agenda through national programs adapted to each countries needs developed by the countries either with or without the assistance of the ILO. They are a self-help tool for member States as well as a tool for the Office to identify gaps so that it can better target technical cooperation and help ILO officials by creating a simple and uniform information base.

To achieve these objectives, the country profiles based on normative indicators contain two types of information. They can be used by member States and the Office to note the progress made towards implementing the decent work agenda in a specific country from one point in time with another. In addition, they provide a detailed appreciation of the national situation with respect to how the indicators are implemented as well as identifying gaps, best practices and possible obstacles. This provides the vital information required to come up with solutions for how better to go forward towards a workplace where decent work is the central pillar.

In view of the above, using the country profiles based on normative indicators as a ranking system could defeat their purpose; that is the promotion and progressive implementation of the standards. Finally given the complex nature of the standards, if the normative indicators are meant to analyse the legal situation in a country with respect to the objectives outlined in the standards, then the result can only be qualitative and not quantitative. 


\section{Appendix 1}

Example of in-depth analysis of OSH Conventions and Recommendations

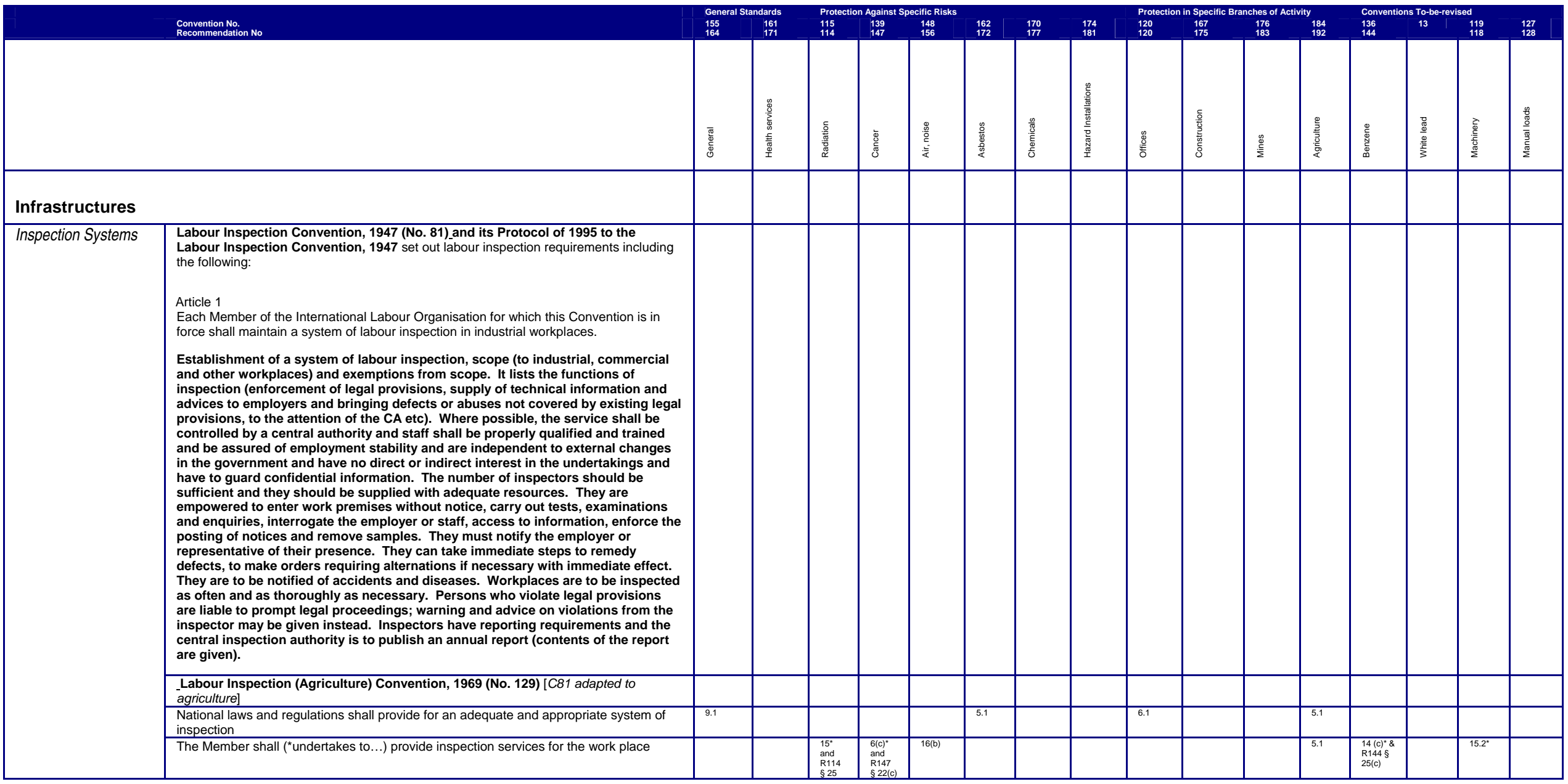




\begin{tabular}{|c|c|c|c|c|c|c|c|c|c|c|c|c|c|c|c|c|}
\hline $\begin{array}{l}\text { Convention No. } \\
\text { Recommendation No }\end{array}$ & $\begin{array}{l}\text { General Sta } \\
155 \\
164\end{array}$ & $\begin{array}{c}\text { ndards } \\
161 \\
171\end{array}$ & $\begin{array}{l}\begin{array}{l}\text { Protec } \\
115 \\
114\end{array} \\
114\end{array}$ & $\begin{array}{c}\text { A against S } \\
\text { 139 } \\
147\end{array}$ & $\begin{array}{c}\text { peefictic Risks } \\
148 \\
156 \\
\end{array}$ & $\begin{array}{l}162 \\
172\end{array}$ & $\begin{array}{l}170 \\
177\end{array}$ & $\begin{array}{l}174 \\
181\end{array}$ & 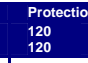 & 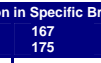 & 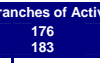 & $\begin{array}{l}\text { ity } \\
\begin{array}{c}184 \\
192 \\
192\end{array} \\
\end{array}$ & 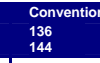 & $\begin{array}{l}\text { ns To-be-rev } \\
13\end{array}$ & $\begin{array}{l}\text { ed } \\
119 \\
118\end{array}$ & $\begin{array}{l}127 \\
128\end{array}$ \\
\hline $\begin{array}{l}\text { The system of inspection provided for in paragraph } 1 \text { of Article } 9 \text { of the } \\
\text { Convention should be guided by the provisions of the Labour Inspection } \\
\text { Convention, 1947, and the Labour Inspection (Agriculture) Convention, } 1969, \\
\text { without prejudice to the obligations thereunder of Members which have ratified } \\
\text { these instruments. }\end{array}$ & R164§ 5 & & & & & & & & & & & & & & & \\
\hline $\begin{array}{l}\text { National Laws or regulations shall designate the authority or authorities responsible both } \\
\text { for supervising the operation of and for advising occupational health services once they } \\
\text { are established }\end{array}$ & & 16 & & & & & & & & & & & & & & \\
\hline $\begin{array}{l}\text { The system of inspection provided for in Article } 5 \text { of the Asbestos Convention, } \\
1986, \text { should be based on the provisions of the Labour Inspection Convention, } \\
1947 \text {. Inspection should be carried out by qualified personnel. The inspection } \\
\text { services should be able to obtain from the employer the information referred to in } \\
\text { Paragraph } 13 \text { above. }\end{array}$ & & & & & & $\begin{array}{l}\text { R172 } \\
\$ 21\end{array}$ & & & & & & & & & & \\
\hline $\begin{array}{l}\text { The competent authority shall have properly qualified and trained staff with the } \\
\text { appropriate skills, and sufficient technical and professional support, to inspect, } \\
\text { investigate, assess, and advise on the matters dealt with in this Convention and to } \\
\text { ensure compliance with national laws and regulations. }\end{array}$ & & & & & & & & 18.1 & & & & & & & & \\
\hline $\begin{array}{l}\text { Appropriate measures should be taken, by adequate inspection or other means, to } \\
\text { ensure the proper application of laws, regulations or other provisions concerning } \\
\text { hygiene. }\end{array}$ & & & & & & & & & $\begin{array}{ll}\mathrm{R} 120 \S \\
83\end{array}$ & & & & & & & \\
\hline $\begin{array}{l}\text { Each Member shall provide appropriate inspection services to } \\
\text { supervise the application of the measures to be taken in pursuance } \\
\text { of the Convention and provide these services with the resources } \\
\text { necessary for the accomplishment of their task, or satisfy itself that } \\
\text { appropriate inspection is carried out. }\end{array}$ & & & & & & & & & & $35(b)$ & 16(b) & & & & & \\
\hline Competent persons shall inspect the work place & & & & & & & & & & 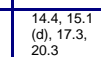 & & & & & & \\
\hline National Laws and regulations shall provide for supervision of safety and health in mines & & & & & & & & & & & $\begin{array}{l}5.2(2) \\
\text { and } \\
\text { R1 } \\
6 \text { 183 }\end{array}$ & & & & & \\
\hline
\end{tabular}




\section{Appendix 2}

International Labour Organisation OSH instruments - relationship between instruments

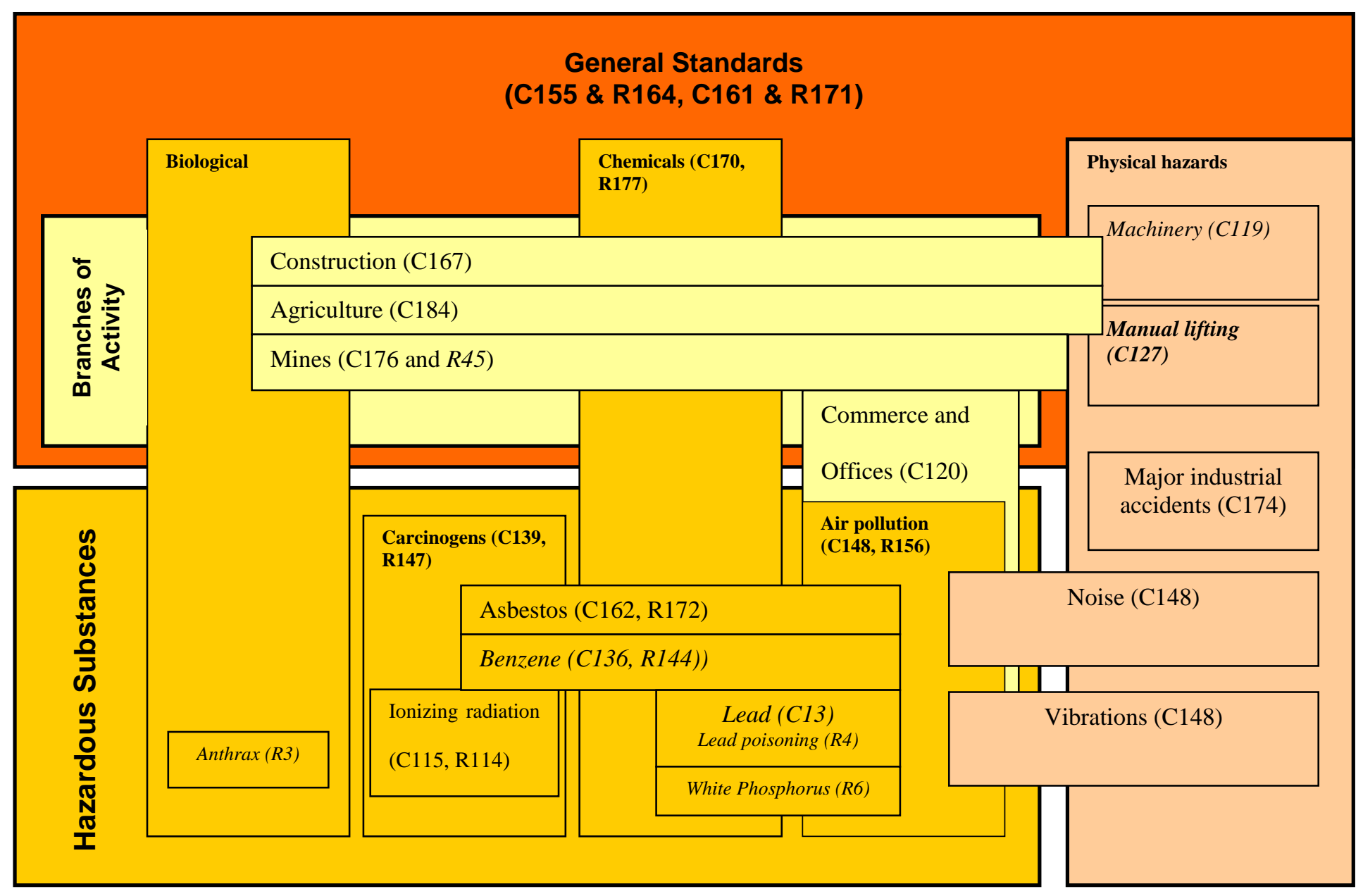




\section{Appendix 3}

Model for a national OSH system

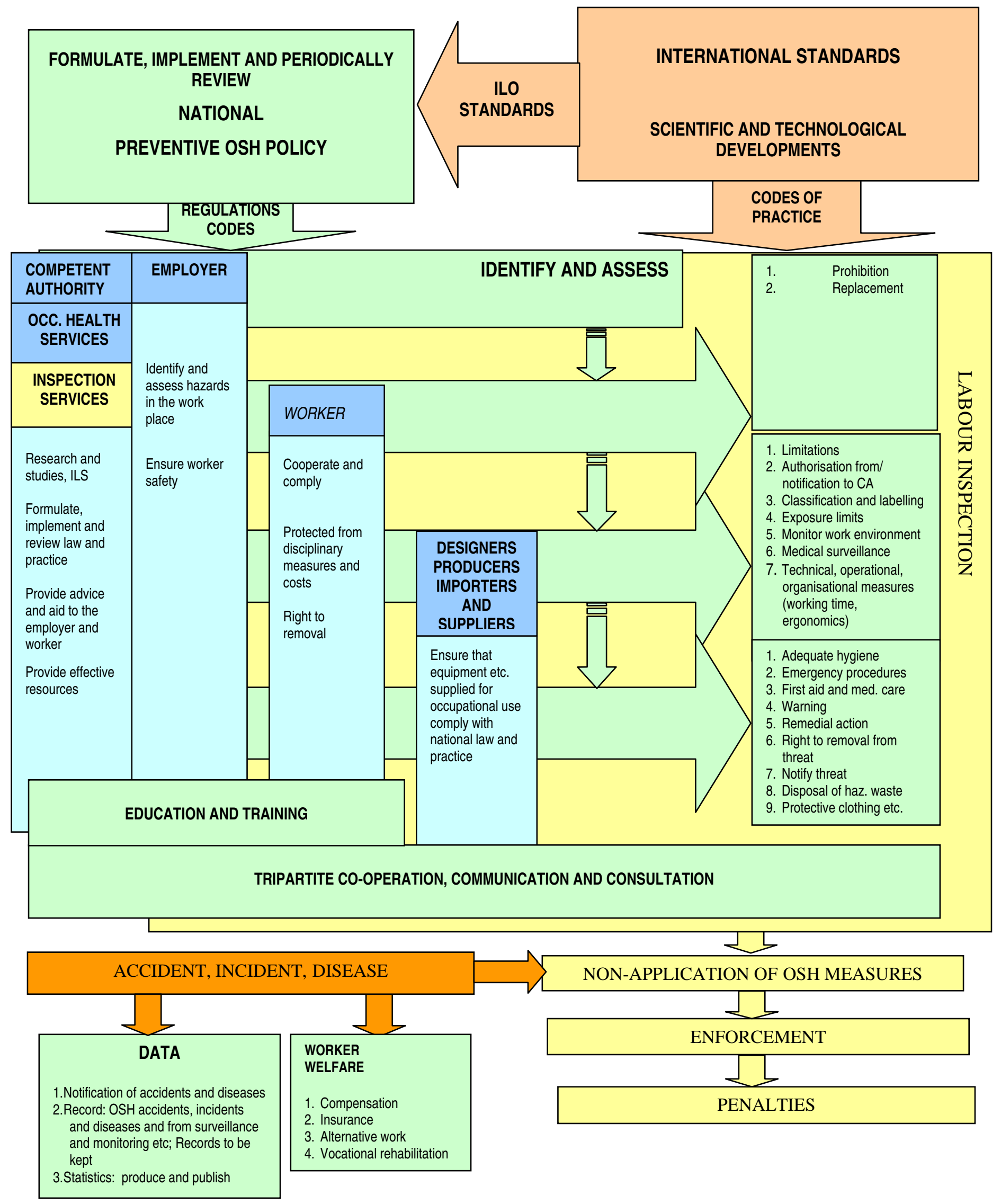




\section{Appendix 4}

Thematic index to the provisions in the instruments examined

\section{Practical guidance}

This index makes reference to the provisions in the relevant instruments listed in Annex I. It follows the order of the questions 1 through 15 in Part I, Section A of the survey. The bolded and italicised text in the questions in the survey correspond to the headings (column three) and keywords (column three) below.

$$
\begin{array}{lll}
\text { Key to the abbreviations in column four } & \text { C: } & \text { Convention } \\
& \text { R: } & \text { Recommendation } \\
\text { CoP: } & \text { Code of Practice (see Annex I, section C) }
\end{array}
$$

\begin{tabular}{|c|c|c|c|}
\hline Q. & Headings & Keywords & Instrument \\
\hline \multicolumn{4}{|c|}{ National OSH policy } \\
\hline 1 & National policy & $\begin{array}{l}\text { Formulation and implementation in } \\
\text { consultation with the most representative } \\
\text { organizations of employers and workers }\end{array}$ & $\begin{array}{l}\text { C155 Art } 4.1 \\
\text { C161 Art 2 } \\
\text { C170 Art 4 } \\
\text { C1774 Art 4 } \\
\text { C116 Art 3 } \\
\text { C184 Art } 4.1\end{array}$ \\
\hline 2 & Periodic review & Mechanisms for the periodic review & $\begin{array}{l}\text { C155 Art } 4.1 \text { and } 7 \\
\text { C161 Art 2 } \\
\text { C162 Art 3.2 } \\
\text { C167 Art 5.2 } \\
\text { C170 Art 4 } \\
\text { C174 Art 4 } \\
\text { C176 Art 3 } \\
\text { C184 Art 4.1 } \\
\text { R164 para 4(b) and 19(a) }\end{array}$ \\
\hline \multicolumn{4}{|c|}{ Scope of application } \\
\hline \multirow[t]{5}{*}{3.} & \multirow[t]{5}{*}{$\begin{array}{c}\text { Branches of economic } \\
\text { activity }\end{array}$} & Exclusions, in whole or in part. & $\begin{array}{l}\text { C120 Art 2 } \\
\text { C148 Art 1.2 } \\
\text { C155 Art } 1.2 \\
\text { C162 Art 1.2 } \\
\text { C167 Art 1.2 } \\
\text { C170 Art 1.2(a) } \\
\text { C174 Art 1.4 } \\
\text { C176 Art 2.2(a) } \\
\text { C184 Art 3.1(a) }\end{array}$ \\
\hline & & A. All branches & $\begin{array}{l}\text { C119 Art 17.1 } \\
\text { C127 Art 2.2 } \\
\text { C148 Art 1.1 } \\
\text { C155 Art 1.1 } \\
\text { C161 Art 3.1 }\end{array}$ \\
\hline & & B. Construction activities & $\begin{array}{l}\text { C167 Art 1.1 } \\
\text { CoP 1992(b) }\end{array}$ \\
\hline & & C. Commerce and office work & C120 Art 1 \\
\hline & & D. Agriculture & C184 Art 1 \\
\hline
\end{tabular}

For the full text of these instruments, please consult the relevant section in the accompanying CD-ROM or the website www.ilo.org. 


\begin{tabular}{|c|c|c|c|c|}
\hline \multirow[t]{3}{*}{ Q. } & \multirow[t]{3}{*}{ Headings } & \multicolumn{2}{|c|}{ Keywords } & \multirow{2}{*}{\begin{tabular}{|l|} 
Instrument \\
C176 Art 2.1 \\
C45 Art 1 \\
CoP 1991(a) \\
\end{tabular}} \\
\hline & & & Mines & \\
\hline & & & Major hazard installations & $\begin{array}{l}\text { C174 Art } 1.2 \\
\text { CoP 1991(b) }\end{array}$ \\
\hline \multirow[t]{11}{*}{4.} & \multirow[t]{11}{*}{ Occupational hazards } & A. & Air pollution & \multirow{3}{*}{$\begin{array}{l}\text { C148 Art 2.1 } \\
\text { CoP 2001(b) Ch. } 4.3-4.5 \\
\text { CoP 2001(c) }\end{array}$} \\
\hline & & & Noise & \\
\hline & & C. & Vibration & \\
\hline & & & Ionising radiations & C115 Art 2.1 \\
\hline & & & Chemicals & $\begin{array}{l}\text { C170 Art } 1.1 \\
\text { CoP } 1993\end{array}$ \\
\hline & & & Carcinogenic substances and agents & C139 Art 1 \\
\hline & & G. & Asbestos & C162 Art 1.1 \\
\hline & & $\mathrm{H}$. & Benzene and products of benzene & C136 Art 1 \\
\hline & & & Lead & C13 Art 1 \\
\hline & & & Machinery & C119 Art 1.1 and 1.3 \\
\hline & & & Manual lifting & $\begin{array}{l}\text { C127 Art 2.1 } \\
\text { CoP 1996 Ch } 11\end{array}$ \\
\hline \multirow[t]{8}{*}{5.} & \multirow[t]{8}{*}{$\begin{array}{c}\text { Specific categories of } \\
\text { workers }\end{array}$} & A. & Young workers & \begin{tabular}{|l} 
C13 Art 3 \\
C127 Art 7 \\
C136 Art 11.2 \\
C155 Art 7.2 \\
C184 Art 16 \\
R192 para. 4.3
\end{tabular} \\
\hline & & B. & Aged workers & $\begin{array}{l}\text { R115 para } 1 \\
\text { R192 para } 4.3 \\
\end{array}$ \\
\hline & & C. & Temporary or seasonal workers & C184 Art 17 \\
\hline & & D. & Migrant workers & R164 para. 4(d), \\
\hline & & & Disabled workers & \begin{tabular}{|l|} 
R115 para. 1 \\
R164 para. $4(\mathrm{~g})$ and 9 \\
\end{tabular} \\
\hline & & F. & Workers in the public sector & \begin{tabular}{|l} 
C161 Art 3.1 \\
C170 Art 2(d) \\
R164 para. 3(a) \\
R171 para. 2.1
\end{tabular} \\
\hline & & G. & Workers in production co-operatives & \begin{tabular}{|l|} 
C161 Art 3.1 \\
C162 art 2(f) \\
R171 para. 2.1 \\
\end{tabular} \\
\hline & & & Self-employed persons & $\begin{array}{l}\text { C119 Art } 13 \\
\text { C167 Art } 1.3 \\
\text { C184 Art } 6.2 \\
\text { R115 para. } 1 \\
\text { R156 para. } 1.2 \\
\text { R164 para. } 1.2 \\
\text { R171 para. } 2.2 \\
\text { R172 para. } 1.2 \\
\text { R177 para. } 1.4 \\
\text { R192 paras. } 12-15\end{array}$ \\
\hline 6. & Gender-specific & \multicolumn{2}{|c|}{ Gender specific provisions related to OSH } & \begin{tabular}{|l} 
C13 Art 3.1 \\
C45 Art 2 and 3 \\
C127 Art 7 \\
C136 Art 11.1 \\
C184 Art 18 \\
R114 para. 16 \\
R177 para. $25(4)$ \\
R192 para. 4.3
\end{tabular} \\
\hline
\end{tabular}




\begin{tabular}{|c|c|c|c|c|}
\hline Q. & Headings & \multicolumn{2}{|c|}{ Keywords } & Instrument \\
\hline \multicolumn{5}{|c|}{ Preventive and protective measures } \\
\hline \multirow[t]{9}{*}{7.} & \multirow[t]{9}{*}{$\begin{array}{c}\text { Technical rules and } \\
\text { measures }\end{array}$} & & Identification and determination & $\begin{array}{l}\text { C139 Art } 1 \\
\text { C148 Art 8.1 } \\
\text { C155 Art 7 and 11(b) } \\
\text { C161 Art 5(a) } \\
\text { C170 Art 10 } \\
\text { C174 Art 5, 7 and 9(a) } \\
\text { C176 Art 7(e) } \\
\text { CoP 2001(c) Ch 2.4 } \\
\end{array}$ \\
\hline & & B. & Prohibition or limitation of exposure & $\begin{array}{l}\text { C139 Art } 1.1 \text { and } 1.3 \\
\text { C155 Art 11(b) } \\
\text { C162 Art } 9\end{array}$ \\
\hline & & C. & Assessment & \begin{tabular}{|l|} 
C155 Art 11(f) \\
C161 Art 5(a) \\
C170 Art 13.1 \\
C174 Art 9(a) \\
C176 Art 6 and 7(e) \\
C184 Art 7(a) \\
CoP 1993 Ch 6.2 \\
CoP 2001(b) Ch 1.1.2 and 3.1 \\
CoP 2001(c) Ch 6.2
\end{tabular} \\
\hline & & D. & Prohibition or limitation of use & $\begin{array}{l}\text { C13 Art } 1.1 \\
\text { C119 Art 2.1 } \\
\text { C136 Art 4.1 } \\
\text { C148 Art 12 } \\
\text { C162 Arts 10(b), } 11.1 \text { and } 12.1\end{array}$ \\
\hline & & & $\begin{array}{l}\text { Exposure limits and related criteria } \\
\text { including periodic revision and } \\
\text { updating of exposure limits }\end{array}$ & $\begin{array}{l}\text { C115 Art 5-8 and R114 para. } 4 \\
\text { C139 Art 2.2 } \\
\text { C136 Art 6.2, } 8.2 \text { and } 11.2 \\
\text { C13 Art 1.2 and 2 } \\
\text { C148 Art } 8 \\
\text { C162 Art 15.1 } \\
\text { C170 Art 6 and 12(a) } \\
\text { CoP 1980 Ch 3 } \\
\text { CoP 2000 Ch 2.4 and Appendix } \\
\text { B and C } \\
\text { CoP 2001(b) Annex I } \\
\text { CoP 2001(c) Ch 2.5 }\end{array}$ \\
\hline & & & Surveillance and monitoring & $\begin{array}{l}\text { C115 Art 11 } \\
\text { C136 Art 6.3 } \\
\text { C161 Art 5(b) and R171 Art 5- } \\
10 \\
\text { CoP } 1993 \text { Ch } 12 \\
\text { CoP 2000 Ch } 7 \\
\text { CoP 2001(a) Ch 1.1.2 } \\
\text { CoP 2001(b) Ch 6.3, } 6.6 \text { and } 15\end{array}$ \\
\hline & & G. & $\begin{array}{l}\text { Replacement of hazardous chemicals } \\
\text { and processes }\end{array}$ & $\begin{array}{l}\text { C136 Art 2.1 } \\
\text { C139 Art 2 } \\
\text { C162 Art 10(a) } \\
\text { C170 Art 13.1(a) } \\
\text { R164 para. 3(h) }\end{array}$ \\
\hline & & H. & Notification, authorization and control & $\begin{array}{l}\text { C139 Art 1 } \\
\text { C148 Art 12 } \\
\text { C155 art 11(b) } \\
\text { C162 Art 9, 13 and } 17 \\
\text { C170 Art 5 } \\
\text { C174 Art 8 } \\
\text { CoP 1991(b) Ch } 11\end{array}$ \\
\hline & & & Classification and labelling & $\begin{array}{l}\text { C115 Art 9.1 } \\
\text { C136 Art 12 } \\
\text { C170 Art 6, 8, 10-11 } \\
\text { C184 Art 12(a) } \\
\text { R164 para. 3(h) } \\
\text { CoP 1993 Ch 3-5 } \\
\text { CoP 1996 Ch 5.5 } \\
\text { CoP 2000 Ch 2.3 and Appendix } \\
\text { A } \\
\text { CoP 2001(c) Ch } 4.2\end{array}$ \\
\hline
\end{tabular}




\begin{tabular}{|c|c|c|c|c|}
\hline Q. & \multirow{2}{*}{\multicolumn{2}{|c|}{ Headings }} & Keywords & \begin{tabular}{|l|} 
Instrument \\
C13 Art 5II (b), (c) \\
C120 Art 17 \\
C136 Art 8.1 \\
C148 Art 10 \\
C155 Art 16.3 \\
C162 Art 15.4 and 18 \\
C167 Art 28(2) and 30
\end{tabular} \\
\hline & & & Personal protective equipment & $\begin{array}{l}\text { C13 Art 5II (b), (c) } \\
\text { C120 Art 17 } \\
\text { C136 Art 8.1 } \\
\text { C148 Art 10 } \\
\text { C155 Art 16.3 } \\
\text { C162 Art 15.4 and 18 } \\
\text { C167 Art 28(2) and 30 } \\
\text { C170 Art 13.1(f) } \\
\text { C174 Art 9(c) } \\
\text { C176 Art 5(b), 6(d) } \\
\text { and 9(c) } \\
\text { R164 para. 3(n) and 10(e) } \\
\text { CoP 1991(a) Ch 23 } \\
\text { CoP 1992(b) Ch 18 } \\
\text { CoP 1993 Ch 9 } \\
\text { CoP 1998 Ch III 7 and } 8 \\
\text { CoP 2000 Ch 4.8 and 4.9 } \\
\text { CoP 2001(c) Ch 5.1 }\end{array}$ \\
\hline & & & $\begin{array}{l}\text { Safe methods for the handling, } \\
\text { collection, recycling and disposal }\end{array}$ & $\begin{array}{l}\text { C162 Art 17.2(c), } 19 \\
\text { C170 Att 14 } \\
\text { C167 Art 28.4 } \\
\text { C184 Art 12(c) and } 13 \\
\text { R164 para. 3(h) } \\
\text { CoP 2000 Ch 4.12 } \\
\text { CoP 2001(c) Ch } 11\end{array}$ \\
\hline & & L. & Working time arrangements & $\begin{array}{l}\text { C148 Art 9(b) and R156 para. } 13 \\
\text { C155 Art 5(b) } \\
\text { C184 Art 20 }\end{array}$ \\
\hline & & M. & $\begin{array}{l}\text { Adaptation of work installations, } \\
\text { machinery, equipment and processes }\end{array}$ & $\begin{array}{l}\text { C155 Art 5(b) } \\
\text { C161 Art 5(e), (g) and (i) }\end{array}$ \\
\hline & & & $\begin{array}{l}\text { Design, construction and layout of } \\
\text { workplaces }\end{array}$ & $\begin{array}{l}\text { C155 Art 5(a) and 11(a) } \\
\text { C148 Art 9(a) } \\
\text { C161 Art 5(c) } \\
\text { R164 para. 3 (a) }\end{array}$ \\
\hline & & O. & $\begin{array}{l}\text { Design, construction, layout, use of } \\
\text { machinery etc. }\end{array}$ & $\begin{array}{l}\text { C119 Part III } \\
\text { C155 Art 5(a) } \\
\text { C167 Art 15-17 and 30(3) } \\
\text { C184 Art 9 and 10 } \\
\text { R156 para. 8, 9 and } 11 \\
\text { R164 para. 3(d) } \\
\text { CoP 1992(b) Ch 7 } \\
\text { CoP 1993 Ch 7 } \\
\text { CoP 1998 Ch III 6 } \\
\end{array}$ \\
\hline & & P. & Adequate welfare facilities & $\begin{array}{l}\text { l13 Art 5II(a) } \\
\text { C120 Art 12,13 } \\
\text { C162 Art 18.5 } \\
\text { C167 Art 32 } \\
\text { C170 Art 13.1(e) } \\
\text { C176 Art 5.4(e) } \\
\text { C184 Art 19(a) } \\
\text { R102 paras. 4-15, 18-20, 23(a), } \\
\text { 24, 25(a), 26-28 } \\
\text { R115 paras. 7(b) and (c), 8(c), } \\
\text { (d) and (f) } \\
\text { R164 para. 3(o) } \\
\text { CoP 1991(a) Ch 22 } \\
\text { CoP 1992(b) Ch 19 } 19 \\
\text { CoP 1993 Ch } 9.5 \\
\text { CoP 2000 Ch } 4.8\end{array}$ \\
\hline
\end{tabular}


Organizational frameworks, mechanisms and measures

\begin{tabular}{|c|c|c|c|c|}
\hline \multirow[t]{3}{*}{8.} & \multirow[t]{3}{*}{ Infrastructures } & & Competent authorities & $\begin{array}{l}\text { C176 Art 5.1 } \\
\text { C184 Art 4.2(a) }\end{array}$ \\
\hline & & B. & Inspection systems & $\begin{array}{l}\text { C81 Art 1, 3-31 } \\
\text { C115 Art 15 } \\
\text { C122 Art 6.1 } \\
\text { C129 Art 3, 6-27 } \\
\text { C139 Art 6(c) } \\
\text { C148 Art 16(b) } \\
\text { C155 Art 9.1 } \\
\text { C162 Art 5.1 } \\
\text { C167 Art 14.4, 15.1(d), } 17.3 \& \\
\text { 20.3 and 35(b) } \\
\text { C176 Art 5.2(a) \& (b), 16(b) } \\
\text { C184 Art 5.1 \& 5.2 }\end{array}$ \\
\hline & & C. & Occupational health services & $\begin{array}{l}\text { C161 Art 3.2, } 5 \text { and } 16 \\
\text { R171 para. } 8-10\end{array}$ \\
\hline \multirow[t]{7}{*}{9.} & \multirow[t]{7}{*}{ Means and measures } & A. & Health surveillance & $\begin{array}{l}\text { C161 Art 5(f) } \\
\text { C176 Art 11 } \\
\text { R164 para. 3(r) } \\
\text { R171 para. 11-18 } \\
\text { CoP 1980 Ch } 4 \\
\text { CoP 1992(a) } \\
\text { CoP 1993 Ch 13 } \\
\text { CoP 2000 Ch 8 } \\
\text { CoP 2001(c) Ch } 16 \\
\end{array}$ \\
\hline & & B. & Medical examinations & $\begin{array}{l}\text { C115 Art 12 } \\
\text { C136 Art } 9.1 \text { and } 10.1 \\
\text { C139 Art 5 } \\
\text { C148 Art 11.1 } \\
\text { C162 Art 21 } \\
\text { CoP 1991(a) Ch } 19.3\end{array}$ \\
\hline & & $\mathrm{C}$. & First aid and emergency treatment & \begin{tabular}{|l|} 
C120 Art 19 \\
C155 Art 18 \\
C161 Art 5(j) \\
C167 Art 31 \\
C176 Art 5.4(a), 9(d) \\
C170 Art 13.2(b) \\
R164 para. 3(p) \\
CoP 1991(a) Ch 19 \\
CoP 1993 Ch 14.2 \\
CoP 1998 Ch III 9.1
\end{tabular} \\
\hline & & D. & Qualification and training & $\begin{array}{l}\text { C81 Art 7 } \\
\text { C115 Art 13(c) } \\
\text { C129 Art 9 } \\
\text { C155 Art 5(c) } \\
\text { C161 Art 11 } \\
\text { C174 Art 18.1 } \\
\text { R171 para. } 36,37 \\
\text { R97 para. } 11 \\
\end{array}$ \\
\hline & & E. & \multicolumn{2}{|c|}{ Consultation, co-operation and coordination } \\
\hline & & a) & $\begin{array}{l}\text { Between various competent authorities } \\
\text { and services }\end{array}$ & $\begin{array}{l}\text { C155 Art 5(d), } 15.1 \\
\text { C161 Art 9.3 } \\
\text { C174 Art 16(c) } \\
\text { C184 Art 4.2(c) } \\
\end{array}$ \\
\hline & & b) & $\begin{array}{l}\text { Between competent authorities and } \\
\text { employers' and workers' organizations }\end{array}$ & $\begin{array}{l}\text { C148 Art 5.1 } \\
\text { C161 Art 4, 6(c) } \\
\text { C162 Art 3.3, 4, 11.2, 12.2, } 22.1 \\
\text { C167 Art 3 } \\
\text { C170 Art 3 } \\
\text { C174 Art 5, } 6 \\
\text { C176 Art 13.3(b) } \\
\text { C184 Art 8.4, 11.1, 16.2, } 19\end{array}$ \\
\hline
\end{tabular}




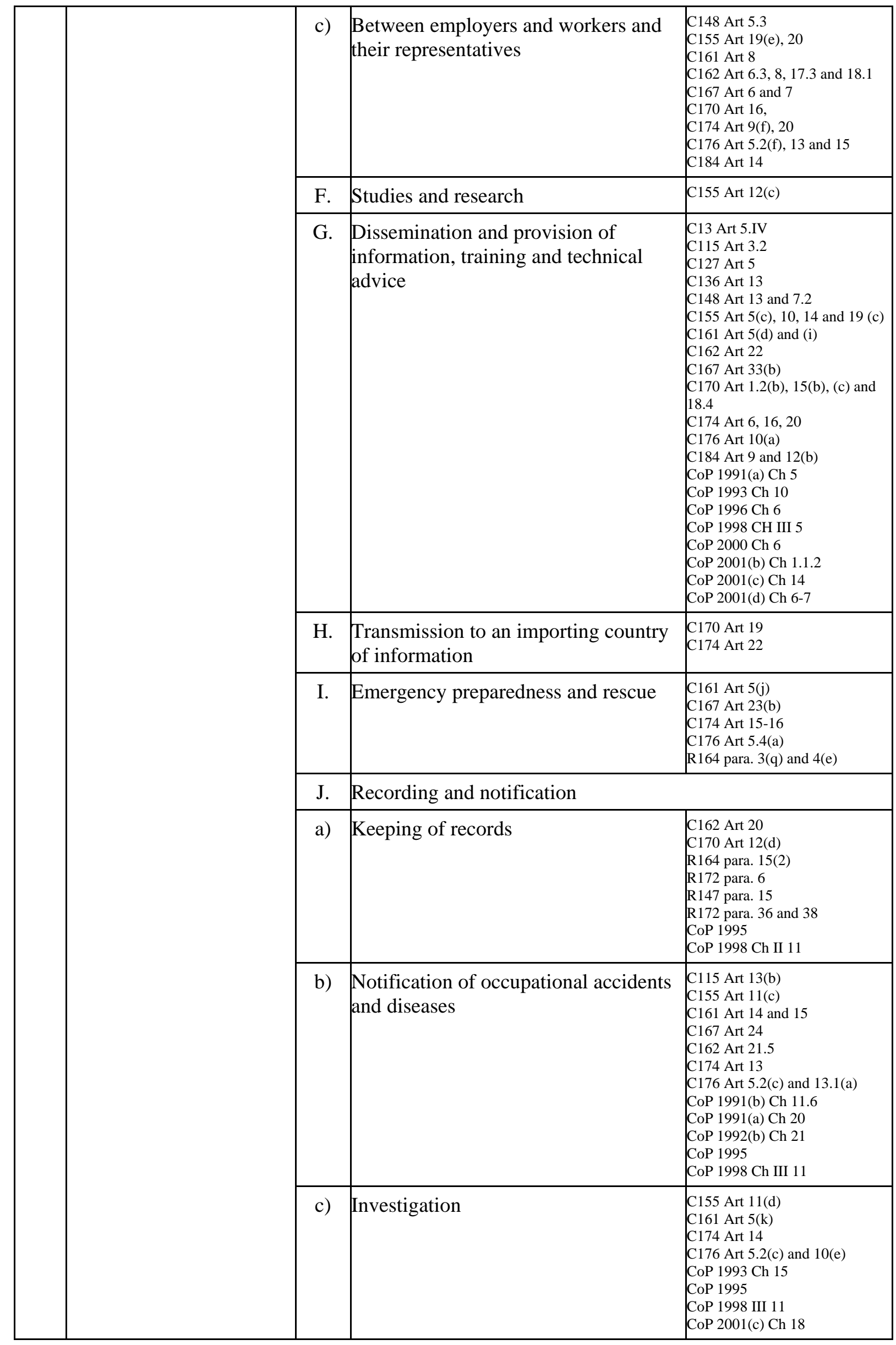




\begin{tabular}{|c|c|c|c|c|}
\hline & & d) & $\begin{array}{l}\text { Compilation and periodic publication } \\
\text { of statistics }\end{array}$ & $\begin{array}{l}\text { C13 Art 7(a) } \\
\text { C176 Art 5.2 (d) } \\
\text { CoP } 1995\end{array}$ \\
\hline 10. & $\begin{array}{l}\text { Implementation of } \\
\text { national OSH } \\
\text { requirements }\end{array}$ & \multicolumn{2}{|c|}{ By methods other than... } & $\begin{array}{l}\text { C155 Art 8 } \\
\text { C115 Art 1 } \\
\text { C139 Art 6(a) } \\
\text { C148 Art 4(2) } \\
\text { C176 Art 4 } \\
\text { C136 Art 14 } \\
\text { C127 art 8 }\end{array}$ \\
\hline \multicolumn{5}{|c|}{ Powers, responsibilities and rights } \\
\hline \multirow[t]{2}{*}{11.} & \multirow[t]{2}{*}{ Enforcement } & A. & Imposition of appropriate penalties & $\begin{array}{l}\text { C81 Art 18 } \\
\text { C129 Art 24 } \\
\text { C148 Art 16(a) } \\
\text { C155 Art 9.1 } \\
\text { C162 Art 5.2 } \\
\text { C167 Art 35(a) } \\
\text { C176 Art 16(a) } \\
\text { C184 Art 4.3 }\end{array}$ \\
\hline & & B. & Suspend, restrict or prohibit work & $\begin{array}{l}\text { C148 Art 12 } \\
\text { C170 Art 5 } \\
\text { C174 Art 19 } \\
\text { C176 Art 5.2(e) } \\
\text { C184 Art 4.3 }\end{array}$ \\
\hline \multirow[t]{6}{*}{12.} & \multirow[t]{6}{*}{$\begin{array}{l}\text { Employer } \\
\text { responsibilities }\end{array}$} & A. & $\begin{array}{l}\text { Establishment of OSH policies and } \\
\text { procedures }\end{array}$ & $\begin{array}{l}\text { C162 Art 17.2 } \\
\text { C174 Art 9-12 } \\
\text { C176 Art 5.5 and 7(g) } \\
\text { R164 para. 14 } \\
\text { CoP 1996 Ch } 3 \\
\text { CoP 1998 Ch 2 } \\
\text { CoP 2001(a) } \\
\text { CoP 2001(c) Ch } .1\end{array}$ \\
\hline & & B. & Monitoring and inspection & $\begin{array}{l}\text { C162 Art 20 } \\
\text { C170 Art 12(c) and (d) } \\
\text { C176 Art 7(e) and 10(b) } \\
\text { R164 para. 10(c), 15.1 }\end{array}$ \\
\hline & & $\mathrm{C}$. & $\begin{array}{l}\text { Emergency response plans and } \\
\text { procedures }\end{array}$ & $\begin{array}{l}\text { C155 Art 18 } \\
\text { C162 Art 6.3 } \\
\text { C170 Art 13.2(c) } \\
\text { C174 Art 9(d) } \\
\text { C176 Art 8 } \\
\text { CoP 2001(c) Ch } 16.3\end{array}$ \\
\hline & & D. & $\begin{array}{l}\text { Provision of information to workers } \\
\text { and their representatives }\end{array}$ & $\begin{array}{l}\text { C119 Art 10.1 } \\
\text { C162 Art 22.3 } \\
\text { C170 Art 10.1, 10.4 and 15(a) } \\
\text { C176 Art 9(a) } \\
\text { C184 Art 9.3 }\end{array}$ \\
\hline & & E. & Education and training & $\begin{array}{l}\text { C155 Art 19(d) } \\
\text { C162 Art 22.3 } \\
\text { C170 Art 15(d) } \\
\text { C10 art 10(a) } \\
\text { C184 Art 7(b) }\end{array}$ \\
\hline & & F. & Remedial action & $\begin{array}{l}\text { C115 Art 13(d) } \\
\text { C155 Art 19(f) } \\
\text { C167 Art 12.2 } \\
\text { C174 Art 9(e) } \\
\text { C176 Art 7(i) and 10(d) } \\
\text { C184 Art 7(c) }\end{array}$ \\
\hline
\end{tabular}




\begin{tabular}{|c|c|c|c|c|}
\hline & & G. & $\begin{array}{l}\text { Establishment of joint safety and health } \\
\text { committees }\end{array}$ & 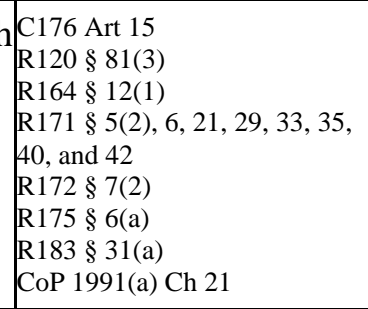 \\
\hline & & $\mathrm{H}$. & Consultation and cooperation & $\begin{array}{l}\text { C148 Art } 6.2 \\
\text { C155 Art 17 } \\
\text { C162 Art } 6.2 \\
\text { C167 Art } 8.1 \text { and } 8.2 \\
\text { C176 Art } 12 \\
\text { C184 Art } 6.2\end{array}$ \\
\hline \multirow[t]{11}{*}{13.} & \multirow[t]{11}{*}{$\begin{array}{l}\text { Worker rights and } \\
\text { responsibilities }\end{array}$} & A. & Access to information & $\begin{array}{l}\text { C148 Art } 7.2 \\
\text { C162 Art } 20.3 \\
\text { C170 Art } 18.3 \\
\text { C174 Art 20(c) } \\
\text { C176 Art 13.1(d) }\end{array}$ \\
\hline & & B. & To be informed & $\begin{array}{l}\text { C115 Art 9.1 } \\
\text { C161 Art 13 } \\
\text { C162 Art 21.3 } \\
\text { C167 Art 33(a) } \\
\text { C174 Art 20(a) and (b) } \\
\text { C176 Art 13.1(c) } \\
\text { C184 Art 8.1(a) }\end{array}$ \\
\hline & & C. & $\begin{array}{l}\text { Participation in inspection and } \\
\text { monitoring }\end{array}$ & $\begin{array}{l}\text { C162 Art 20.4 } \\
\text { C167 Art 10 } \\
\text { C176 Art 13.1(b) and 13.2(b)(i) } \\
\text { C184 Art 8.1(b) } \\
\end{array}$ \\
\hline & & D. & $\begin{array}{l}\text { Selection of worker safety } \\
\text { representatives }\end{array}$ & $\begin{array}{l}\text { C176 Art 13.1(f) } \\
\text { C184 Art 8.1(b) }\end{array}$ \\
\hline & & E. & Removing themselves from danger & $\begin{array}{l}\text { C155 Art 19(f) } \\
\text { C167 Art 12.1 } \\
\text { C170 Art 18.1 } \\
\text { C174 Art 20(e) } \\
\text { C176 Art 13(e) } \\
\text { C184 Art 8.1(c) }\end{array}$ \\
\hline & & F. & $\begin{array}{l}\text { Being protected from disciplinary } \\
\text { measures }\end{array}$ & $\begin{array}{l}\text { C155 Art 5(e) and } 13 \\
\text { C170 Art 18.2 } \\
\text { C174 Art 20(e) } \\
\text { C184 Art 8.1(c) }\end{array}$ \\
\hline & & G. & $\begin{array}{l}\text { Incurring no personal cost for personal } \\
\text { protective equipment }\end{array}$ & $\begin{array}{l}\text { 1) } 136 \text { Art } 10.2 \\
\text { C148 Art 11.2 } \\
\text { C155 Art } 21 \\
\text { C162 Art 15.4, 21.2 } \\
\text { C176 Art 9(c) and 10(a) }\end{array}$ \\
\hline & & $\mathrm{H}$. & Cooperation and compliance & $\begin{array}{l}\text { C148 Art 7.1 } \\
\text { C155 Art 19(a) } \\
\text { C162 Art 7 } \\
\text { C170 Art 17.1 } \\
\text { C174 Art 21 } \\
\text { C184 Art } 8.2\end{array}$ \\
\hline & & I. & Taking reasonable care & $\begin{array}{l}\text { C119 Art 11 } \\
\text { C127 Art 3 } \\
\text { C167 Art 11(b) } \\
\text { C170 Art 17.2 } \\
\text { C176 Art 14(b) } \\
\end{array}$ \\
\hline & & $\mathrm{J}$. & Personal protective equipment & $\begin{array}{l}\text { C119 Art } 11 \\
\text { C167 Art } 11(\mathrm{c}) \text { and } 30.4 \\
\text { R164 para. } 16(\mathrm{c})\end{array}$ \\
\hline & & $\mathrm{K}$. & Immediate reporting to the supervisor & $\begin{array}{l}\text { C155 Art 19(f) } \\
\text { C170 Art 18(1) } \\
\text { C174 Art 20(e) } \\
\text { C176 Art 14(c) }\end{array}$ \\
\hline
\end{tabular}




\begin{tabular}{|c|c|c|c|c|}
\hline \multirow[t]{5}{*}{14.} & \multirow[t]{5}{*}{$\begin{array}{c}\text { Rights and } \\
\text { responsibilities of } \\
\text { workers' representatives }\end{array}$} & A. & Consultation on OSH matters & $\begin{array}{l}\text { C155 Art 19(c) and (e) } \\
\text { C162 Art 17.3 } \\
\text { C174 Art 20(c) } \\
\text { C176 Art 13.2(e) and (d) }\end{array}$ \\
\hline & & B. & Participation in inspections & $\begin{array}{l}\text { C148 Art 5.4 and } 7.2 \\
\text { C161 Art 8 } \\
\text { C162 Art 20.4 } \\
\text { C174 Art 18.2 } \\
\text { C176 Art 13 }\end{array}$ \\
\hline & & C. & Access to information & $\begin{array}{l}\text { C148 Art 7.2 } \\
\text { C155 Art 19(c) } \\
\text { C162 Art 20.3 } \\
\text { C170 Art 18.3 } \\
\text { C174 Art 20 } \\
\text { C176 Art 13.2(f) }\end{array}$ \\
\hline & & D. & Appeal & \begin{tabular}{|l} 
C148 Art 7.2 \\
C162 Art 20.4
\end{tabular} \\
\hline & & $\mathrm{E}$ & Cooperation & $\begin{array}{l}\text { C155 Art 19(b) } \\
\text { C184 Art 8.2 }\end{array}$ \\
\hline \multirow[t]{3}{*}{15.} & \multirow{3}{*}{$\begin{array}{c}\text { Responsibilities of } \\
\text { designers, producers } \\
\text { importers and suppliers }\end{array}$} & A. & $\begin{array}{l}\text { Design, production, importation supply } \\
\text { and disposal process }\end{array}$ & $\begin{array}{l}\text { C119 Art 2.3, 2.4 } \\
\text { C155 Art 12(a) } \\
\text { C167 Art 9 }\end{array}$ \\
\hline & & B. & Labelling and marking & $\begin{array}{l}\text { C162 Art 14 } \\
\text { C170 Art 9.1(a) and (c) }\end{array}$ \\
\hline & & C. & Adequate safety and health information & $\begin{array}{l}\text { C155 Art 12(b) } \\
\text { C170 Art 9.1(d) and } 9.2 \\
\text { C184 Art 9.2 } \\
\text { CoP 2000 Ch } 3.1 \text { and } 4.3\end{array}$ \\
\hline
\end{tabular}




\section{Appendix 5}

\section{Grid for $\mathrm{OSH}$}

\begin{tabular}{|c|c|c|}
\hline ILO OSH criteria & Sub-criteria & $\begin{array}{c}\text { Reference to detailed } \\
\text { table of OSH } \\
\text { standards }\end{array}$ \\
\hline \multirow{4}{*}{$\begin{array}{l}\text { 1. The existence of a } \\
\text { national OSH policy } \\
\text { formulated, } \\
\text { implemented and } \\
\text { reviewed on a } \\
\text { tripartite basis }\end{array}$} & \multicolumn{2}{|l|}{ A national OSH policy: } \\
\hline & a) Exists and is implemented & Page 6 \\
\hline & $\begin{array}{l}\text { b) Has been formulated in consultation with the most } \\
\text { representative Employers' and Workers' organizations }\end{array}$ & Page 8 \\
\hline & c) Is subject to periodic reviewed & Page 8 \\
\hline \multirow{22}{*}{$\begin{array}{l}\text { 2. Coverage of } \\
\text { national OSH } \\
\text { legislation }\end{array}$} & $\begin{array}{l}\text { National OSH legislation covers all branches of economic } \\
\text { activity }\end{array}$ & Page 10 \\
\hline & National OSH legislation covers all categories of workers & Page 14-15 \\
\hline & $\begin{array}{l}\text { Existence of specific provisions for other branches of activity or } \\
\text { occupational hazards }\end{array}$ & Page $10-13$ \\
\hline & $\begin{array}{l}\text { Existence of exclusions from the application of OSH provisions } \\
\text { in whole or in part of branches of economic activity, or of } \\
\text { specific categories of workers }\end{array}$ & Page 16-19 \\
\hline & \multicolumn{2}{|c|}{$\begin{array}{l}\text { National OSH legislation includes provisions applicable to the following branches of } \\
\text { economic activity: }\end{array}$} \\
\hline & a) Construction & Pages 10, 20-23 \\
\hline & b) Commerce and offices & Pages 10, 20-23 \\
\hline & c) Agriculture & Pages $11,20-23$ \\
\hline & d) Mines & Pages $11,20-23$ \\
\hline & e) Major hazard installations & Pages $12,20-23$ \\
\hline & \multicolumn{2}{|c|}{$\begin{array}{l}\text { National OSH legislation includes provisions concerning the following occupationa } \\
\text { hazards: }\end{array}$} \\
\hline & a) Air pollution & Pages $11,20-23$ \\
\hline & b) Noise & Pages $11,20-23$ \\
\hline & c) Vibration & Pages $11,20-23$ \\
\hline & d) lonising radiations & Pages $11,20-23$ \\
\hline & e) Chemicals & Pages $11,20-23$ \\
\hline & f) Carcinogenic substances and agents & Pages $11,20-23$ \\
\hline & g) Asbestos & Pages $11,20-23$ \\
\hline & h) Benzene and products of benzene & Pages $11,20-23$ \\
\hline & i) Lead & Pages $11,20-23$ \\
\hline & j) Machinery & Pages $12,20-23$ \\
\hline & k) Manual lifting & Pages $12,20-23$ \\
\hline
\end{tabular}




\begin{tabular}{|c|c|c|}
\hline \multirow{17}{*}{$\begin{array}{l}\text { 3. Existence of } \\
\text { national preventive } \\
\text { and protective OSH } \\
\text { measures }\end{array}$} & \multicolumn{2}{|c|}{ Existence of technical OSH rules and measures including in relation to: } \\
\hline & a) The identification and determination of occupational hazards & Page 25 \\
\hline & $\begin{array}{l}\text { b) The prohibition, limitation or other means of control of } \\
\text { exposure }\end{array}$ & Page 30 \\
\hline & c) The assessment of risks and levels of exposure & Pages 28 \\
\hline & $\begin{array}{l}\text { d) Prohibition or limitation of use of hazardous processes, } \\
\text { machinery and equipment and hazardous chemical, physical } \\
\text { and biological agents }\end{array}$ & Page 29 \\
\hline & $\begin{array}{l}\text { e) The specification of exposure limits and related criteria } \\
\text { including periodic revision and updating of exposure limits }\end{array}$ & Page 33-36 \\
\hline & f) The surveillance and monitoring of the working environment & Page 36-38 \\
\hline & $\begin{array}{l}\text { g) The replacement of hazardous chemicals and processes by } \\
\text { less hazardous ones }\end{array}$ & Page 38 \\
\hline & $\begin{array}{l}\text { h) The notification of hazardous work and the related } \\
\text { authorization and control requirements }\end{array}$ & Page 39 \\
\hline & $\begin{array}{l}\text { i) The classification and labelling of hazardous chemicals and } \\
\text { the provision of related data sheets }\end{array}$ & Page 41 \\
\hline & j) The provision and use of personal protective equipment & Page 47 \\
\hline & $\begin{array}{l}\text { k) Safe methods for the handling, collection, recycling, and } \\
\text { disposal of hazardous waste }\end{array}$ & Page 46 \\
\hline & $\begin{array}{l}\text { l) Working time arrangements (such as hours of work and rest } \\
\text { periods, etc. }\end{array}$ & Page 51 \\
\hline & $\begin{array}{l}\text { m) Adaptation of work installations, machinery, equipment and } \\
\text { processes to the physical and mental capacities of the workers, } \\
\text { taking ergonomic factors into account? }\end{array}$ & Page 52 \\
\hline & $\begin{array}{l}\text { n) Design, construction, layout and maintenance of workplaces } \\
\text { and installations }\end{array}$ & Page 52 \\
\hline & $\begin{array}{l}\text { o) Design, construction, layout, use, maintenance, testing and } \\
\text { inspection of machinery, tools and equipment }\end{array}$ & Page 55 \\
\hline & $\begin{array}{l}\text { p) The provision of adequate welfare facilities (such as drinking } \\
\text { water and sanitary eating and changing facilities) }\end{array}$ & Page 60 \\
\hline \multirow{4}{*}{$\begin{array}{l}\text { 4. Existence of } \\
\text { national OSH } \\
\text { infrastructures }\end{array}$} & \multicolumn{2}{|l|}{ Existence of: } \\
\hline & a) Competent authority(ies) responsible for $\mathrm{OSH}$ & Page 67 \\
\hline & b) A system of inspection & Page 69 \\
\hline & c) Occupational health services & Page 71 \\
\hline \multirow{5}{*}{$\begin{array}{l}\text { 5. Capacity and } \\
\text { functioning of } \\
\text { national OSH } \\
\text { infrastructures }\end{array}$} & \multicolumn{2}{|l|}{ National OSH infrastructures are: } \\
\hline & a) Provided with adequate resources & Page 71 \\
\hline & b) Equipped with qualified and trained staff & Page 71 \\
\hline & $\begin{array}{l}\text { c) To establish measures for the dissemination and provision of } \\
\text { information on OSH matters }\end{array}$ & Page 94 \\
\hline & $\begin{array}{l}\text { d) To establish measures for training and education on } \mathrm{OSH} \\
\text { matters. }\end{array}$ & Page 100 \\
\hline
\end{tabular}




\begin{tabular}{|c|c|c|}
\hline \multirow{5}{*}{$\begin{array}{l}\text { 6. Notification and } \\
\text { recording of } \\
\text { occupational } \\
\text { accidents and } \\
\text { diseases }\end{array}$} & \multicolumn{2}{|c|}{$\begin{array}{l}\text { The existence of measures for the recording and notification of occupational accidents } \\
\text { and diseases including: }\end{array}$} \\
\hline & $\begin{array}{l}\text { a) The establishment and keeping of records of occupational } \\
\text { accidents and diseases }\end{array}$ & Page 104 \\
\hline & $\begin{array}{l}\text { b) Notification of occupational accidents and diseases to the } \\
\text { competent authorities }\end{array}$ & Page 105 \\
\hline & c) Investigation into occupational accidents and diseases. & Page 109 \\
\hline & $\begin{array}{l}\text { d) Compilation and periodic publication of statistics on } \\
\text { occupational accidents and diseases }\end{array}$ & Page 110 \\
\hline \multirow{5}{*}{$\begin{array}{l}\text { 7. Occupational } \\
\text { health }\end{array}$} & \multicolumn{2}{|l|}{ Existence of national mechanisms and /or measures: } \\
\hline & a) For health surveillance & Page 77 \\
\hline & b) For regular medical examinations & Page 80 \\
\hline & c) The provision of first aid and emergency treatment & Page 81 \\
\hline & d) Emergency preparedness and rescue & Page 84 \\
\hline \multirow{4}{*}{$\begin{array}{l}\text { 8. Existence of } \\
\text { measures for } \\
\text { consultation, } \\
\text { cooperation and } \\
\text { communication at all } \\
\text { levels }\end{array}$} & \multicolumn{2}{|c|}{ Measures to ensure consultation, co-operation and coordination on OSH between: } \\
\hline & a) The various competent authorities and services? & Page 86 \\
\hline & $\begin{array}{l}\text { b) The competent authorities and employers' and workers' } \\
\text { organizations? }\end{array}$ & Page 88 \\
\hline & $\begin{array}{l}\text { c) The employers and workers and their representatives within } \\
\text { the enterprise }\end{array}$ & Page 89 \\
\hline \multirow{2}{*}{$\begin{array}{l}\text { 9. Existence of } \\
\text { enforcement } \\
\text { mechanisms }\end{array}$} & $\begin{array}{l}\text { Existence of mechanisms for the imposition of appropriate } \\
\text { penalties in cases of infringement of laws and regulations }\end{array}$ & Page 111 \\
\hline & $\begin{array}{l}\text { Empowerment of the competent authorities to suspend, restrict } \\
\text { or prohibit work where there is a serious threat to the health and } \\
\text { safety of workers, until appropriate corrective measures have } \\
\text { been implemented? }\end{array}$ & Page 112 \\
\hline \multirow{8}{*}{$\begin{array}{l}\text { 10. Employer } \\
\text { responsibilities }\end{array}$} & \multicolumn{2}{|l|}{ Employer responsibilities include: } \\
\hline & $\begin{array}{l}\text { a) Establishment of OSH policies and procedures to implement } \\
\text { the preventive and protective measures prescribed by national } \\
\text { law and practice }\end{array}$ & Page 115 \\
\hline & $\begin{array}{l}\text { b) Monitoring and inspection of the workplace, processes, } \\
\text { machinery, tools equipment and other material elements of work }\end{array}$ & Page 116 \\
\hline & c) Establishment of emergency response plans and procedures & Page 117 \\
\hline & $\begin{array}{l}\text { d) Provision of information to workers and their representatives } \\
\text { concerning occupational hazards }\end{array}$ & Page 118 \\
\hline & e) Education and training of workers & Page 119 \\
\hline & f) Taking of appropriate remedial action after any accident & Page 120 \\
\hline & $\begin{array}{l}\text { g) Establishment of a mechanism for consultation and } \\
\text { cooperation on OSH matters between employers where there is } \\
\text { more than one employer in a workplace or work site }\end{array}$ & Page 121 \\
\hline
\end{tabular}




\begin{tabular}{|c|c|c|}
\hline \multirow{12}{*}{$\begin{array}{l}\text { 11. Workers' rights } \\
\text { and responsibilities }\end{array}$} & \multicolumn{2}{|l|}{ Workers rights and responsibilities include: } \\
\hline & $\begin{array}{l}\text { a) Access to information relevant to OSH held by the competent } \\
\text { authorities and the employer }\end{array}$ & Page 122 \\
\hline & $\begin{array}{l}\text { b) Being kept informed on workplace hazards and consulted on } \\
\text { related OSH measures }\end{array}$ & Page 123 \\
\hline & $\begin{array}{l}\text { c) Participation in inspection and monitoring activities and the } \\
\text { review of OSH measures }\end{array}$ & Page 125 \\
\hline & d) Selection of a worker safety representative & Page 126 \\
\hline & $\begin{array}{l}\text { e) Removing themselves from danger in case of imminent and } \\
\text { serious risk to their health }\end{array}$ & Page 126 \\
\hline & $\begin{array}{l}\text { f) Being protected from disciplinary measures due to actions } \\
\text { taken in accordance with OSH requirements }\end{array}$ & Page 128 \\
\hline & $\begin{array}{l}\text { g) Incurring no personal cost for the implementation of OSH } \\
\text { measures including training and the provisions of personal } \\
\text { protective equipment }\end{array}$ & Page 129 \\
\hline & $\begin{array}{l}\text { h) Cooperation with the employer and compliance with OSH } \\
\text { measures }\end{array}$ & Page 130 \\
\hline & $\begin{array}{l}\text { i) Taking reasonable care of their personal safety and that of } \\
\text { others in the workplace }\end{array}$ & Page 130 \\
\hline & j) Making proper use of personal protective equipment & Page 131 \\
\hline & $\begin{array}{l}\text { k) Immediate reporting to the supervisor of any situation } \\
\text { presenting a threat to safety }\end{array}$ & Page 127 \\
\hline \multirow{6}{*}{$\begin{array}{l}\text { 12. Workers' } \\
\text { representatives rights } \\
\text { and responsibilities }\end{array}$} & \multicolumn{2}{|l|}{ Rights and responsibilities of workers' representatives include: } \\
\hline & a) Consultation on OSH matters with the employer & Page 132 \\
\hline & $\begin{array}{l}\text { b) Participation in inspections, monitoring and investigations } \\
\text { related to OSH with }\end{array}$ & Page 135 \\
\hline & $\begin{array}{l}\text { c) Access to information on OSH matters held by the competent } \\
\text { authorities and the employer }\end{array}$ & Page 133 \\
\hline & $\begin{array}{l}\text { d) The right to appeal to the competent authorities on OSH } \\
\text { matters }\end{array}$ & Page 136 \\
\hline & e) Cooperation with the employer on OSH matters & Page 136 \\
\hline \multicolumn{3}{|c|}{$\begin{array}{l}\text { 13. Responsibilities of Responsibilities of designers, producers, importers and suppliers include: } \\
\text { designers, producers, } \\
\text { importers and }\end{array}$} \\
\hline suppliers & $\begin{array}{l}\text { a) Taking into account of safety and health requirements and } \\
\text { concerns in the design, production, importation, supply and } \\
\text { disposal processes }\end{array}$ & Page 137 \\
\hline & b) Adequate labelling and marking of products & Page 138 \\
\hline & $\begin{array}{l}\text { c) Making available to the user of adequate safety and health } \\
\text { information on their products }\end{array}$ & Page 139 \\
\hline
\end{tabular}




\section{Appendix 6}

DRAFT - Grid for migrant worker country profile

\begin{tabular}{|c|c|c|}
\hline $\begin{array}{l}\text { ILO Migrant } \\
\text { Worker } \\
\text { Criteria }\end{array}$ & & $\begin{array}{l}\text { Relevant provisions in } \\
\text { instruments }\end{array}$ \\
\hline \multirow[t]{3}{*}{$\begin{array}{l}\text { Providing } \\
\text { assistance in the } \\
\text { migration process }\end{array}$} & Provision of information to migrant workers & $\begin{array}{l}\text { C97 Art. 2, Annex I Art. 5.1(c) } \\
\text { and Annex II Art. 6.1(c) and } \\
\text { R86 Para. 5; } \\
\text { C143 Art. 12(c) and R151 Para } \\
\text { 7; } \\
\text { C169 Art. 20.3(a); } \\
\text { R164, Para. 4(d); } \\
\text { R188 Para. 8(b) }\end{array}$ \\
\hline & $\begin{array}{l}\text { Measures to facilitate the departure, journey, } \\
\text { reception and return of migrant workers }\end{array}$ & $\begin{array}{l}\text { C97 Art. } 4 \text { and Annex I, Art 6(c) } \\
\text { and R86 Paras. 1, } 10 \text { and 20; } \\
\text { C110 Art. 18; } \\
\text { C168 Art. 26(i) }\end{array}$ \\
\hline & $\begin{array}{l}\text { Medical services for and prevention of health risks } \\
\text { to migrant workers and members of their family }\end{array}$ & $\begin{array}{l}\text { C97 Art. 5; } \\
\text { R151 Para. 20; } \\
\text { C110 Art. } 11 \text { and } 19\end{array}$ \\
\hline \multirow[t]{2}{*}{$\begin{array}{l}\text { Recruitment } \\
\text { measures }\end{array}$} & Regulation of recruitment and placement practices & $\begin{array}{l}\text { C97 Art. } 7 \text { and Annex I and II; } \\
\text { R86 Paras. 13, } 14 \text { and 19; }\end{array}$ \\
\hline & $\begin{array}{l}\text { Measures against misleading propaganda and } \\
\text { fraudulent activities }\end{array}$ & $\begin{array}{l}\text { C97 Art. 3; } \\
\text { C110 Art. 17; } \\
\text { C181 Art. } 8\end{array}$ \\
\hline \multirow[t]{9}{*}{$\begin{array}{l}\text { Equality of } \\
\text { opportunity and } \\
\text { treatment between } \\
\text { national and } \\
\text { regular migrant } \\
\text { workers }\end{array}$} & $\begin{array}{l}\text { Employment conditions (remuneration, hours of } \\
\text { work, rest periods, overtime, holidays, homework, } \\
\text { minimum age, apprenticeship, vocational training, } \\
\text { security of employment and OSH measures) }\end{array}$ & $\begin{array}{l}\text { C97 Art. } 6.1(\mathrm{a})(\mathrm{i}) ; \\
\text { C143 Arts. } 8.2 \text { and 10; } \\
\text { R151 Para. 2; } \\
\text { C100 Art. 2; } \\
\text { C111 Art. 2; } \\
\text { C169 Art. } 20.3\end{array}$ \\
\hline & Trade union membership & $\begin{array}{l}\text { C97 Art. 6.1(a)(ii); } \\
\text { C87 Art. } 2\end{array}$ \\
\hline & $\begin{array}{l}\text { Living conditions (housing, social services, } \\
\text { educational institutions and health) }\end{array}$ & $\begin{array}{l}\text { C97 Art. } 6.1(\mathrm{a})(\mathrm{iii}) \\
\text { R151 Para. 2(i); } \\
\text { R115 Para. } 5\end{array}$ \\
\hline & Social security & $\begin{array}{l}\text { C97 Art. } 6.1(\mathrm{~b}) ; \\
\text { C143 Art. 10; } \\
\text { R151 Para. 2(f); } \\
\text { C102 Part XII; C110 Art. 52; } \\
\text { C121 Art. 27; C130 Art. 32 }\end{array}$ \\
\hline & $\begin{array}{l}\text { Keeping of acquired rights and receiving benefits } \\
\text { abroad }\end{array}$ & $\begin{array}{l}\text { C143 Art. 9.1; } \\
\text { R151 Para. 34; } \\
\text { C118 Arts. 4.1, 5.1 and 6; } \\
\text { C157 Parts III and IV; } \\
\text { C110 Arts. 52-53; } \\
\text { R157 Para. 69(b) }\end{array}$ \\
\hline & Employment taxes & C97 Art. 6.1(c) \\
\hline & Access to legal proceedings & C97 Art. 6.1(d) \\
\hline & Free choice of employment & $\begin{array}{l}\text { C143 Art. } 14(\mathrm{a}) \text { and }(\mathrm{c}) \\
\text { R86 Para. } 16\end{array}$ \\
\hline & Recognition of professional qualifications & C143 Art. 14(b) \\
\hline
\end{tabular}




\begin{tabular}{|c|c|c|}
\hline $\begin{array}{l}\text { ILO Migrant } \\
\text { Worker } \\
\text { Criteria }\end{array}$ & & $\begin{array}{l}\text { Relevant provisions in } \\
\text { instruments }\end{array}$ \\
\hline \multirow[t]{2}{*}{$\begin{array}{l}\text { Guarantees in } \\
\text { case of } \\
\text { termination of } \\
\text { employment }\end{array}$} & $\begin{array}{l}\text { Authorisation for migrant worker admitted on a } \\
\text { permanent basis to stay in case of incapacity to } \\
\text { work }\end{array}$ & C97 Art. 8.1 and 8.2 \\
\hline & $\begin{array}{l}\text { Upon loss of employment migrant workers to be } \\
\text { allowed sufficient time to find alternative } \\
\text { employment and not to be regarded as illegal or in } \\
\text { irregular position }\end{array}$ & $\begin{array}{l}\text { C143 Art 8.1; } \\
\text { R151 Para. } 31\end{array}$ \\
\hline $\begin{array}{l}\text { Allowing for the } \\
\text { transfer of assets }\end{array}$ & $\begin{array}{l}\text { Allow migrant worker to transfer earnings, savings, } \\
\text { personal effects, tools, equipment and capital }\end{array}$ & $\begin{array}{l}\text { C97 Art. } 9 \text { and Annex III; } \\
\text { R86 Para. } 10(d)\end{array}$ \\
\hline $\begin{array}{l}\text { Family } \\
\text { reunification }\end{array}$ & Facilitating family reunification & $\begin{array}{l}\text { C143 Art. 13; } \\
\text { R86 Para. 15; } \\
\text { R151 Paras. 13-16 }\end{array}$ \\
\hline \multirow{8}{*}{$\begin{array}{l}\text { Preventing abuses } \\
\text { of and protecting } \\
\text { migrant workers in } \\
\text { an irregular } \\
\text { situation }\end{array}$} & $\begin{array}{l}\text { Recognition of fundamental rights for all migrant } \\
\text { workers }\end{array}$ & C143 Art. 1 \\
\hline & $\begin{array}{l}\text { Equality of treatment in respect of trade union } \\
\text { membership for migrant workers in an irregular } \\
\text { situation }\end{array}$ & $\begin{array}{l}\text { C87 Art. } 2 \\
\text { R151 Para. } 8.3\end{array}$ \\
\hline & $\begin{array}{l}\text { Detection of irregular migration and illegal } \\
\text { employment }\end{array}$ & $\begin{array}{l}\text { C143 Arts. } 2 \text { and } 4 ; \\
\text { C182 Art. } 8\end{array}$ \\
\hline & $\begin{array}{l}\text { Measures suppress manpower trafficking and } \\
\text { establishment of sanctions against organisers of } \\
\text { trafficking }\end{array}$ & $\begin{array}{l}\text { C143 Arts. 3, } 5 \text { and 6; } \\
\text { C97 Annex I Art. } 8 \text { and Annex II } \\
\text { Art. 13; } \\
\text { C29 Arts. } 1 \text { and 25; } \\
\text { C105 Art. } 1 \text { and 2; } \\
\text { C182 Art. } 3 \text { and } 7\end{array}$ \\
\hline & $\begin{array}{l}\text { Measures suppress illegal employment and } \\
\text { imposition of appropriate sanctions }\end{array}$ & C143 Art. 3 and 6 \\
\hline & $\begin{array}{l}\text { Migrant workers who face expulsion shall have the } \\
\text { right to appeal against order and granted a stay of } \\
\text { execution of the expulsion order }\end{array}$ & $\begin{array}{l}\text { C143 Art. 9.2; } \\
\text { R151 Para. } 33\end{array}$ \\
\hline & $\begin{array}{l}\text { Cost of expulsion not to be borne by migrant } \\
\text { worker }\end{array}$ & C143 Art. 9.3 \\
\hline & Possibility to regularise irregular migrant workers & C143 Art. 9.4 \\
\hline
\end{tabular}




\section{Policy Integration Department Working Papers}

No. 1 ILO activities on the social dimension of globalization: Synthesis report

No. 2 Measuring decent work with statistical indicators

Richard Anker, Igor Chernyshev, Philippe Egger, Farhad Mehran and Joseph Ritter

No. 3 Globalization and decent work: Options for Panama Philippe Egger

No. 4 Globalización y trabajo decente: Opciones para Panamá Philippe Egger

No. 5 Indicators of social dialogue: Concepts and measurements Lane Kenworthy and Bernhard Kittel

No. 6 Assessing the impact of the attacks of 11 September 2001 on women's employment in the United States

Gertrude Schaffner Goldberg and Helen Lachs Ginsburg

No. 7 Decent work and the informal economy in Central America Juan Diego Trejos Solórzano and Miguel Del Cid

No. 8 Poverty initiatives in the ILO: A review of past and present approaches Pat Holden and Dagmar Walter

No. 9 Whither the International Standard Classification of Occupations (ISCO-88)? Debbie Budlender

No. 10 Improving occupational classifications as tools for describing labour markets: A summary of recent national experiences Debbie Budlender

No. 11 Recent developments in China's labour economy Thomas G. Rawski

No. 12 The Impact of economic liberalization on employment and wages in India Sonia Bhalotra

No. 13 The impact of trade liberalization upon inequality in developing countries Donald J. Robbins

No. 14 The impact of liberalization and globalization on income inequality in developing and transitional economies Giovanni Andrea Cornia

No. 15 The impact of technology transfer on employment and income distribution in developing countries: A survey of theoretical models and empirical studies Mariacristina Piva 


\section{Policy Integration Department Working Papers \\ Prepared by the World Commission on the \\ Social Dimension of Globalization}

No. 16 International finance: Meeting the needs of people in developing countries José Guilherme Almeida dos Reis

No. 17 The gender dimensions of globalization of production Stephanie Barrientos, Naila Kabeer and Naomi Hossain

No. 18 Social exclusion in the context of globalization - Jan Breman

No. 19 Gender and globalization: A macroeconomic perspective Çağatay Nilüfer and Ertük Korkurt

No. 20 Globalization, social exclusion, and work: with special reference to informal employment and gender - Marilyn Carr and Martha Chen

No. 21 Resources for social development - Antony Clunies Ross

No. 22 Does the new international trade regime leave room for industrialization policies in the middle-income countries? - Alisa DiCaprio and Alice Amsden

No. 23 Social dimension of globalization in Latin America: Lessons from Bolivia and Chile, Ivaro García Hurtado

No. 24 The social dimension of globalization: a review of the literature Bernhard Gunter and Rolph van der Hoeven

No. 25 The social dimension of global production systems: A review of the issues, Susan Hayter

No. 26 Reforming global economic and social governance: a critical review of recent programmatic thinking - Jeremy Heimans

No. 27 Corporate social responsibility: an issues paper - Michael Hopkins

No. $28 \quad$ Upgrading in global value chains - John Humphrey

No. 29 Implications of globalization and economic restructuring for skills development in Sub-Saharan Africa - Richard K. Johanson

No. 30 The outcome and impact of the main international commissions on development issues Frédéric Lapeyre

No. 31 Globalization and structural adjustment as a development tool - Frédéric Lapeyre

No. 32 Globalization and perceptions of social inequality - Malte Luebker

No. 33 The changing structure of international trade linked to global production systems: what are the policy implications? - William Milberg

No. 34 Corporate social responsibility: an overview of principles and practice,Jill Murray

No. 35 Inclusive development strategy in an era of globalization - Ignacy Sachs

No. 36 Social consequences of the globalization of the media and communication sector: some strategic considerations - Seán Ó. Siochrú

No. 37 Globalization, history and international migration: a view from Latin America Andrés Solimano

No. 38 Towards a different kind of globalization, or how the anti-globalists view the world Gijsbert van Liemt 


\section{Policy Integration Department Working Papers}

No. 39 How do trade union rights affect trade competitiveness? David Kucera and Ritash Sarna

No. 40 Statistics on the employment situation of people with disabilities:

A compendium of national methodologies

ILO Bureau of Statistics in collaboration with the In Focus Programme on Skills, Knowledge and Employability

No. 41 Employment in the informal economy in the Republic of Moldova ILO Bureau of Statistics in collaboration with the Department for Statistics and Sociology of the Republic of Moldova

No. 42 Decent work in a least developed country: A critical assessment of the Ethiopia PRSP Graeme J. Buckley

No. 43 Unemployment and Labour Market Institutions: The Failure of the Empirical Case for Deregulation Dean Baker, Andrew Glyn, David Howell and John Schmitt

No. 44 Women's access to occupations with authority, influence and decision-making power: Women as legislators, senior officials and managers around the world Richard Anker.

No. 45 The world of work in the context of economic integration and trade liberalization Daniel Martínez

No. 46 Poverty reduction in Pakistan: The strategic impact of macro and employment policies Moazam Mahmood

No. 47 Trends in Work Stoppages: A Global Perspective L. J. Perry and Patrick J. Wilson

No. 48 Generating decent work for poverty reduction in Cambodia: The voice of workers, employers and the Government Moazam Mahmood

No. 49 The Social Dimension of Regional Integration in ECOWAS René Robert

No. 50 Measuring trade union rights: A country-level indicator constructed from coding violations recorded in textual sources David Kucera

No. 51 Patterns of job quality attributes in European Union Joseph A. Ritter

No. 52 Child Labour, Education and Export Performance

David Kucera and Ritash Sarna 
No. 53 Measuring the informal economy: From employment in the informal sector to informal employment

Ralf Hussmanns

No. 54 Indicators of labour standards: an overview and comparison

Richard N. Block

No. 55 The pattern of globalization and some implications for the pursuit of social goals Gerry Rodgers

No. 56 Statistical indicators of social dialogue: A compilation of multiple country databases Anne Chataigner

No. 57 Trade unions and informal workers' associations in the urban informal economy of Ecuador - Catherine Vaillancourt-Laflamme

No. 58 Decent work, standards and indicators

Monique Zarka-Martres and Monique Guichard-Kelly 